\title{
Review Article \\ Review on Major Food-Borne Zoonotic Bacterial Pathogens
}

\author{
Engidaw Abebe $\mathbb{D}$, Getachew Gugsa, and Meselu Ahmed \\ School of Veterinary Medicine, Wollo University, Dessie, Ethiopia \\ Correspondence should be addressed to Engidaw Abebe; engidawabebe24@gmail.com
}

Received 13 January 2020; Accepted 19 May 2020; Published 29 June 2020

Academic Editor: Aditya Prasad Dash

Copyright (C 2020 Engidaw Abebe et al. This is an open access article distributed under the Creative Commons Attribution License, which permits unrestricted use, distribution, and reproduction in any medium, provided the original work is properly cited.

\begin{abstract}
Food-borne microorganisms are major pathogens affecting food safety and cause human illness worldwide as a result of consumption of foodstuff, mainly animal products contaminated with vegetative pathogens or their toxins. Most of these microbes have zoonotic importance resulting in significant impact on both public health and economic sectors. Bacteria are the causative agents of two-thirds of human food-borne diseases worldwide with high burden in developing countries. Hence, the objectives of this review paper are to highlight the background of food-borne bacterial pathogens and to review common major food-borne zoonotic bacterial pathogens. Food animals are the major reservoirs of many food-borne zoonotic bacterial pathogens, and food products of animal origin are the main vehicles of transmission. Meat, dairy products, and eggs are the main ways by which people are exposed to zoonotic bacteria. S. aureus, Salmonella species, Campylobacter species, L. monocytogenes, and E. coli are the major zoonotic bacterial pathogens which are the causative agents of food-borne illness and death in the world associated with consumption of contaminated animal products. Production of toxins and structural virulent factors are responsible for the pathogenesis of these bacteria. These major zoonotic bacteria cause human infections which are characterized mainly by gastrointestinal symptoms including nausea, vomiting, diarrhea, abdominal cramps, and other agent-specific symptoms. Some bacteria may cause severe complications. Conventional (culturing), serological, and molecular techniques are important for detection of these common zoonotic bacteria and their toxins in food. Good hygiene, GMP, sanitation in operating procedures, and implementation of standardized HACCP and pasteurization procedures are effective methods for the control and prevention. Currently, the emergence of multidrug-resistant zoonotic bacteria associated with consumption of contaminated animal products is a great concern for the public health, and there should be coordinated surveillance and monitoring system for food-borne zoonotic bacterial pathogens particularly in developing countries including Ethiopia.
\end{abstract}

\section{Introduction}

Ethiopia is believed to have the largest livestock population in Africa, with an estimated population of $60,392,019$ cattle, 31,302,257 sheep, 32,738,385 goats, 2,007,829 horses, 461,665 mules, 8,845,589 donkeys, 1,418,457 camels, $56,056,778$ poultry, and $6,523,969$ beehives [1]. The livestock sector contributes about $45 \%$ to the agricultural gross domestic product (GDP), $18.7 \%$ to the national GDP, and $16-19 \%$ to the total foreign exchange earnings of the country. It is the source of industrial raw materials (milk, meat, and hides and skin) and high-value protein to potential consumers in Ethiopia [2].

The consumption of animal products like meat, milk, and egg is increased due to rapid human population growth, urbanization, per capita income raise, globalization, and the changes on consumer habits (preference of high-protein diet). This situation results in a high demand of food of animal origin and leads to intensive animal production and processing of products, especially mass production and movement of products globally. During this time, there may be defective processing practices at any point of the farm to fork chain which increase the chances of contamination and spread of food-borne pathogens $[3,4]$.

Food products may become contaminated at different stages along the food chain [5], could be during production, processing, distribution, preparation, and/or final consumption. The risk of food getting contaminated depends largely on the health status of the food handlers, their personal hygiene, knowledge, and practice of food hygiene [6]. 
According to World Health Organization (WHO), foodborne diseases are defined as diseases of infectious or toxic nature which are caused by the consumption of food or water [7]. Intoxication (toxin produced by the pathogens causes food poisoning), infection (ingestion of food containing pathogens), and toxicoinfections (producing toxins while growing in the human intestines) are the three types of food-borne diseases $[3,8]$.

Diseases of animal origin can be transmitted between humans and animals through direct contact, indirect environmental contact, and/or through food consumption [9]. Around $60 \%$ of human diseases are originated from animals, and approximately $75 \%$ of new emerging human infectious diseases are transmitted from vertebrate animals to humans [10].

Food-borne pathogens are microorganisms (i.e., bacteria, viruses, and fungi) as well as a number of parasites [11], and they are the primary cause of food spoilage and foodborne diseases [5]. Food-borne microbes are major problems affecting food safety and cause human infections after consumption of the animal products contaminated with microorganisms or their toxins [4].

Most of the pathogens have a zoonotic origin, and food products of animal origin are considered as major vehicles of food-borne infections [12]. Food-producing animals (cattle, chickens, pigs, turkeys, etc.) are the major reservoirs for many food-borne pathogens [4]. Animal products (meat, milk, egg, fish, etc.) and their products have high risk due to pathogen contents, natural toxins, adulterants, and other possible contaminants [13], and the risk of food-borne diseases in humans is increasing when consumption of food of animal origin is increased [14].

In recent years, food-borne pathogens become an important public health problem worldwide, and their impact on health (significant morbidity and mortality rate) and economy is increasingly recognized [5, 11, 15-17]. According to different reports, a huge number of people suffer from food-borne diseases each year worldwide [12], and around 600 million (10 people in the world) become ill due to the consumption of contaminated food [18]. Due to unrecognized or unreported outbreaks, statistical data of food-borne diseases are increased [5].

Food-borne diseases are major health problems both in developed and developing countries [19], but developing countries tend to suffer from the largest share of the burden of food-borne diseases [16]. According to the WHO, 30\% of the population suffer from food-borne diseases each year in developed countries, and up to 2 million deaths are estimated per year in developing countries [19].

Nowadays, the awareness has been growing on the public health impact of zoonotic food-borne pathogens transmitted from animal-originated food [20]. There is emergence of new pathogens, and the way of transmission of known foodborne pathogens is changing or is now associated with new food vehicles [15]. The prevalence of multidrug-resistant (MDR) food-borne pathogens is increased after consumption of contaminated food due to the use of drugs for human therapy and animal farming which are responsible for more serious disease than susceptible bacteria [5, 21]. Drug resistance among the pathogens in common and food-borne pathogens in particular is an emerging problem $[15,22]$.

Prevailing poor food handling and sanitation practices, inadequate food safety laws, weak regulatory systems, lack of financial resources to invest in safer equipment, and lack of education for food handlers are the reasons for common occurrence of food-borne diseases in developing countries including Ethiopia [13, 16, 23, 24]. The habit of raw beef consumption [25], overcrowding, poverty, inadequate sanitary conditions, and poor general hygiene are also the factors of food-borne diseases in Ethiopia [26].

The public health importance of several bacterial pathogens associated with food of animal origin has been shown by studies conducted in different parts of the country [13]. However, there is a lack of reliable statistics on food-borne diseases as well as well-organized and documented information on the occurrence of such diseases due to poor or nonexistent reporting systems in Ethiopia as well as in most developing countries.

Therefore, the objectives of this review paper are as follows:

To highlight about the background information of food-borne bacterial pathogens

To review common major food-borne zoonotic bacterial pathogens

\section{Food-Borne Zoonotic Bacterial Pathogens}

2.1. General Background. Food-borne diseases occur as a result of consumption of contaminated food stuffs especially from animal products [26-29]. Food poisoning syndrome results from ingestion of a wide variety of food contaminated with pathogenic organisms (bacteria, viruses, parasites, and fungi) and their toxin and chemicals. Bacteria (66\%), chemicals (26\%), virus (4\%), and parasites (4\%) are the main causes of food-borne diseases [8]. Currently, food-borne disease caused by bacterial contamination is one of the biggest issues affecting human health and food safety [30].

Bacteria are the causative agent of two-thirds of foodborne disease outbreaks though there have been around 250 different food-borne diseases [31]. From the biological hazards, bacterial pathogens are the most serious concern regarding the issues of meat safety to consumers [32]. Bacterial food-borne illnesses are among the most widely spread global public health problems in recent times [8].

Vertebrate animal species are natural reservoirs for many pathogens that cause human infections after transmitted through food [33]. Food of animal origin particularly meat (beef, mutton, and pork), dairy products (milk, cheese, yoghurt, and ice cream), and eggs are the three ways by which people are exposed to pathogenic bacteria [19]. Due to their nutritional value, mainly high protein and lipid content, dairy products are a suitable growth environment for a range of microorganisms [34]. Contaminated raw meat is one of the main sources of food-borne disease [26].

Food of animal origin (milk, meat, and their products) can become contaminated with bacteria during food processing or slaughtering [35]. These pathogens come into 
contact with food during harvest or slaughtering, processing, storage, and packaging. Environmental challenges have caused food-borne bacterial pathogens to evolve and the susceptibility of the human population to infections [5]. The battle against bacterial food-borne diseases is facing new challenges due to rapidly changing patterns of human consumption, the globalization of the food market, and climate change [31].

Food-borne bacterial diseases caused by bacteria are most commonly prevented and controlled by proper cooking and preparing of food as well as storing. The control method or measures also include education of those who prepare the food at home and other food handlers, prohibiting individuals with abscess or other skin lesions from handling food, and placing of food in a cold place at $4^{\circ} \mathrm{C}$ or lower temperature which prevent bacterial multiplication and toxin formation. Food must be kept at room temperature for as little time as possible [8].

\subsection{Common Major Food-Borne Zoonotic Bacterial} Pathogens. Among the bacteria that cause food-borne poisoning, some are particularly important in terms of frequency and/or of seriousness of the disease. Miscellaneous bacteria (including Gram positive and Gram negative) produce toxins that cause food-borne poisoning, resulting symptoms ranging from gastrointestinal disorders to paralysis and death [36]. It has been reported that Gramnegative bacteria account for approximately $69 \%$ of the cases of bacterial food-borne disease [24].

Although there are 31 pathogens that have been identified as causing food-borne diseases [11], bacterial pathogens including Staphylococcus aureus (S. aureus), Salmonella species, Campylobacter species, Listeria monocytogenes ( $L$. monocytogenes), and Escherichia coli (E. coli) are the common causes of food-borne diseases and death in the world $[5,11,20,27,37]$.

2.2.1. Staphylococcus aureus. The name Staphylococcus (staphyle = bunch of grapes in Greece) was introduced in 1883 by Ogston [31]. S. aureus is one of the most common food-borne pathogens worldwide [21, 38] with high occurrence second to salmonellosis [39].

It is a microorganism that is present as a commensal on the skin, nose, and mucous membranes of healthy humans and animals [39, 40]. However, it is a well-known opportunistic food-borne pathogen $[41,42]$ that can cause multiple infectious diseases of diverse severity [40]. It causes wide spectrum of diseases in both humans and animals [43].

The presence of $S$. aureus in products for human consumption is important to the food industry, as some strains are the cause of food-borne intoxication [21]. They are responsible for food spoilage, reduction of food safety, and shelf life and cause food-borne poisoning [44]. S. aureus is a leading cause of food poisoning resulting from the consumption of contaminated food with staphylococcal enterotoxins [45].

It earns public attention due to increasing mortality associated with multidrug resistance [21]. The widespread use of antibiotics and ability of the bacteria to rapidly develop and acquire antimicrobial resistance have facilitated the emergence of resistant strains such as methicillin-resistant S. aureus (MRSA) [41, 42, 46]. The emergence of MRSA in livestock and the possibility of human crosscontamination have caused a serious concern [38].

MRSA were first reported in the early 1960s and are now regarded as a major hospital-acquired pathogen worldwide [47]. MRSA is a well-known pathogen occurring both in human and veterinary medicine $[21,48]$.

(1) Etiology. The genus Staphylococcus comprises several species and subspecies [44]. S. aureus is a Gram-positive, catalase-positive, coagulase-positive, usually oxidasenegative, and facultative anaerobic coccus, which belongs to the family of Micrococcaceae [43, 49]. It is a nonmotile bacterium. Cells are spherical single and often form grapelike clusters [31]. Gold colony pigmentation, production of coagulase, fermentation of mannitol and trehalose, and production of heat stable thermonuclease distinguish $S$. aureus from other staphylococcal species [49]. The organisms are able to grow in a wide range of temperatures $\left(7^{\circ} \mathrm{C}\right.$ to $48^{\circ} \mathrm{C}$ with an optimum of $30^{\circ} \mathrm{C}$ to $\left.37^{\circ} \mathrm{C}\right), \mathrm{pH}(4.2$ to 9.3, with an optimum of 7.0 to 7.5 ), and sodium chloride concentrations (up to $15 \% \mathrm{NaCl}$ ). These characteristics enable the bacteria to survive in a wide variety of food, especially those that require manipulation during processing, including fermented food products like cheese [31].

(2) Epidemiology. The epidemiology of this microorganism in animals has gained interest because of its importance in veterinary medicine, the increment of infectious processes caused by this pathogen (especially MRSA strains), and the emergence of some clonal lineages associated with animals, and zoonotic potential evidence is increased in the last years [40]. S. aureus is among the leading causes of food-borne bacterial intoxications worldwide [50]. It is one of the most common causes of reported food-borne diseases in the United States [7].

Around 50\% of healthy individuals harbor the bacteria in their nasal passage, throat, and skin, whereas the mastitic cow is a common source of $S$. aureus in raw milk [51]. It is widely present in a broad host range, including human beings and food-producing animals, such as pigs, cows, goats, chickens, and ducks [42]. Food contamination with $S$. aureus may occur directly from infected food-producing animals or may result from poor hygiene during production processes or the retail and storage of food [52].

A multifactorial range of independent risk factors for MRSA has been reported in the literature, and factors include immunosuppression hemodialysis, peripheral malperfusion, advanced age, extended in hospital stays, residency in long-term care facilities, inadequacy of antimicrobial therapy, indwelling devices, insulin-requiring diabetes, and decubitus ulcers, among others [53].

Studies that have been conducted in different regions of Ethiopia indicated the occurrence of $S$. aureus in food of animal origin as few of them are given in Table 1 . 
TABle 1: Prevalence of $S$. aureus in food of animal origin in different parts of Ethiopia.

\begin{tabular}{|c|c|c|c|}
\hline Sample type & $\begin{array}{c}\text { No. of } \\
\text { examined }\end{array}$ & $\begin{array}{l}\text { No. of positive } \\
\text { (prevalence) }\end{array}$ & Source \\
\hline Raw bulk milk & 168 & $79(47)$ & \\
\hline $\begin{array}{l}\text { Naturally soured/fermented raw } \\
\text { milk }\end{array}$ & 51 & $13(25.4)$ & \\
\hline Butter milk & 44 & $14(31.8)$ & \\
\hline Butter & 32 & $8(25)$ & Enquebaher et al.[51]; Tigray Region, Northern Ethiopia \\
\hline Ethiopian cottage cheese & 7 & $2(28.6)$ & \\
\hline Cheese & 4 & $2(50)$ & \\
\hline Cakes made from milk & 4 & $2(50)$ & \\
\hline Total & 310 & $120(38.7)$ & \\
\hline Abattoir & 384 & $36(9.4)$ & \multirow{6}{*}{ Adugna et al. [54]; Addis Ababa city } \\
\hline Butcher & 384 & $76(19.8)$ & \\
\hline Cutting table & 40 & $6(15)$ & \\
\hline Hook & 40 & $6(15)$ & \\
\hline Knife & 40 & $9(22.5)$ & \\
\hline Total & 888 & $133(15)$ & \\
\hline Raw cow milk & 170 & $48(28.2)$ & $\begin{array}{c}\text { Tessema and Tsegaye [39]; Alage Atvet College Dairy Farm, } \\
\text { Ethiopia }\end{array}$ \\
\hline Raw cow milk & 140 & $45(32.14)$ & Tessema [55]; Wolayta Sodo \\
\hline Milk shop & 86 & $20(23.26)$ & \\
\hline Dairy milk & 86 & $23(26.74)$ & Abraha et al. [43]; Mekelle town \\
\hline Total & 172 & $43(25)$ & \\
\hline Milk and milk products & 291 & $68(23.4)$ & \multirow{5}{*}{$\begin{array}{c}\text { Ayele et al. [56]; Sebeta } \\
\text { Regasa et al. [57]; Mukaturi and Sululta town, Oromia } \\
\text { Region } \\
\text { Daka et al. [58]; Hawassa area } \\
\text { Hassan et al. [59]; Asella } \\
\text { Serda et al. [60]; Jigjiga district }\end{array}$} \\
\hline Milk & 183 & $28(15.3)$ & \\
\hline Milk & 160 & $78(48.75)$ & \\
\hline Beef carcass swab & 400 & $137(34.3)$ & \\
\hline Raw camel milk & 384 & $44(11.45)$ & \\
\hline
\end{tabular}

(3) Transmission. S. aureus is transmitted from the contaminated animal-source foodstuff $[7,31,54]$. This bacterium has the potential to contaminate animal products and may enter the food chain during processing, preparation, wrapping, mincing, and storage [42].

$S$. aureus food contamination can occur in different kinds of food resources such as livestock and poultry products and seafood, as well as bakery products, which often contain enterotoxigenic strains [38]. Various food items can be contaminated by staphylococcal enterotoxins, especially moist food containing starch and protein [30].

Several food materials including milk and dairy products [19], pork, beef, mutton, poultry, and eggs are common vehicles that are frequently implicated in Staphylococcal food poisoning [42]. Raw meat is a good medium for $S$. aureus survival and spread of drug-resistant $S$. aureus in the community [61]. Additionally, food handlers carrying $S$. aureus on their bodies or gloves can also contaminate food [42].

(4) Pathogenesis. S. aureus has a variety of virulence factors that, singly and in combination, can result in severe infection [51]. A wide spectrum of secreted and cell surface-associated virulence factors can be expressed to promote adhesion to the host extracellular matrix components, damage host cells, and fight the immune system [62]. The extracellular active substances that the organism produces which are thought to contribute to the pathogenicity of the organism include coagulase, hemolysins, nuclease, acid phosphatase, lipase, protease, fibrinolysin, enterotoxins, and toxic shock syndrome toxins [21].

If food is stored for some time in room temperature, the organism in the food can produce its toxin. The bacteria produce enterotoxin while multiplying in food [31]. The enterotoxins are proteolytic, enzyme-resistant, and heatstable, and they may be present in food when $S$. aureus are absent $[31,54]$.

The enterotoxins are classified into 23 different staphylococcal enterotoxins (SEs) and SE-like toxins [30, 41, 42] including the six major serologically different types $(\mathrm{A}, \mathrm{B}$, $\mathrm{C} 1, \mathrm{C} 2, \mathrm{D}$, and E) that differ in toxicity [31]. However, little is known about the prevalence of MRSA in food involved in international trade or about their enterotoxin production [41].

Enterotoxins stimulate the central nervous system (CNS) vomiting center and inhibit water and sodium absorption in the small intestine [8]. They are responsible for symptoms of acute gastroenteritis [31].

(5) Symptoms. The bacteria can cause various diseases with different symptoms, ranging from simple skin infection to more serious and potentially life-threatening infections such as septicemia, necrotizing fasciitis, infective endocarditis, necrotizing pneumonia, and toxic shock syndrome [42, 46].

The disease has short incubation period (clinical signs appear within 2-4 hrs after consumption of food) [8]. It is 
characterized by nausea and vomiting, mainly subnormal temperature, chills, headache [3], and abdominal cramping with or without diarrhea [7] but no fever [42]. Abdominal cramps, nausea, and vomiting are the most common [7]. Death occasionally occurs among more susceptible individuals, such as children and the elderly population [42].

MRSA strains or multidrug-resistant $S$. aureus cause nosocomial infections responsible for rapidly progressive, potential fatal diseases including life-threatening pneumonia, necrotizing fasciitis, endocarditis, osteomyelitis, severe sepsis, and toxinoses such as toxic shock syndrome [53].

(6) Detection. A range of selective and diagnostic media have been developed to assist in the detection and enumeration of Staphylococci in routine food surveillance programmes and food poisoning investigations [31]. Diagnostic microbiology laboratories and reference laboratories are the key for identifying outbreaks of MRSA [47].

The most widely used and generally accepted criterion for identification of pathogenic Staphylococci is usually by their ability to produce coagulase. A common medium used for the isolation of pathogenic Staphylococci is the mannitol salt agar [31]. Currently available standard method for the detection of coagulase-positive Staphylococci including $S$. aureus in food is based on selective enrichment and subsequent isolation of colonies with characteristic morphology and identification by microbiological and biochemical-based confirmations [63].

Molecular biological-based and immunological techniques are also considered as important tools for investigating $S$. aureus contaminations [42]. Real-time polymerase chain reaction (RT-PCR) and quantitative PCR are increasingly being employed in clinical laboratories for the rapid detection and identification of MRSA strains. Another common laboratory test is a rapid latex agglutination test [47].

The most important methods used to detect enterotoxins in food are the enzyme-linked immunosorbent assay (ELISA) method and other screening methods [31]. Other serologic tests including agglutination test [30] and gel diffusion can be employed to detect and identify enterotoxins [8]. Molecular biological methods like nucleic acid hybridization, PCR, and fluorescent immunoassays are the most popular approaches for the detection of enterotoxins in recent times [30].

(7) Prevention and Control. Staphylococci are ubiquitous and are impossible to eliminate from the environment. Prevention of staphylococcal infections/intoxication requires strategies to interrupt various modes of transmission [31]. Cooking food thoroughly, preventing contamination and cross-contamination, and maintaining critical points are effective ways to prevent staphylococcal infections. Public awareness regarding safe meat-handling and other public health interventions could be a cornerstone in preventing the outbreak [7].

Control programs include improvements in personal hygiene practices among healthcare workers and food handlers, decontamination of equipment, surfaces, clothing, judicious use of antibiotics, proper cooking and storage of food, and screening programs [31].

Microbiological guidelines such as Hazard Analysis and Critical Control Points (HACCP), Good Manufacturing Practice (GMP), and good hygienic practices developed by the WHO and the United States Food and Drug Administration should be implemented strictly to prevent $S$. aureus contamination [7]. Areas where MRSA patients are nursed should be thoroughly cleaned using disinfectants [47].

\subsubsection{Nontyphoidal Salmonella. Nontyphoidal Salmonella} are most important zoonotic bacterial food-borne pathogens of humans. Salmonellae are widely distributed in nature [64], and they are the major pathogenic bacteria in humans as well as in animals [65]. They are most frequently isolated bacterial agents of food-borne disease outbreaks [66], and they account around 93.8 million food-borne illnesses and 155,000 deaths per year worldwide [4]. Salmonella has been found to be the major cause of food-borne diseases and a serious public health problem in the world, with an increasing concern for the emergence and spread of antimicrobial-resistant strains [12] including in industrialized countries [67]. Antibiotic-resistant Salmonella infections of both humans and animals are universal concerns, particularly in developing countries [12].

Apart from the morbidity and mortality costs in humans and animals, restrictions to trade and discard contaminated food are important socioeconomic problems of the bacteria [68].

(1) Etiology. Salmonella comprises greater than 2,500 identified serotypes [69] which are included under two species Salmonella enterica (S. enterica) and Salmonella bongori ( $S$. bongori). S. enterica is further classed into six subspecies [3] and is a major pathogen in humans as well as in animals $[67,69]$. More than 150 serotypes can cause foodborne salmonellosis [3]. However, S. typhimurium and $S$. enteritidis are more common $[3,67,68]$. Those bacteria are Gram-negative, relatively anaerobic, nonspore forming, and straight rods belonging to the Enterobateriaceae family [9] that are indistinguishable from $E$. coli under the microscope or ordinary nutrient media [8].

(2) Epidemiology. Salmonella is one of the major public health concerns all over the world [70]. It is the most common food-borne diseases in both developing and developed countries, although incidence rates vary according to the country [65].

The prominent epidemiological factor is the common carrier status in animals [71]. Salmonella is found naturally in the environment and in both domestic and wild animals [4]. The primary habitat of Salmonella species is the intestinal tract of the animals such as farm animals, humans, birds, reptiles, and insects. Animals are the reservoir of foodborne diseases of Salmonella [8].

Nontyphoidal Salmonella species are zoonotic agents, and food products of animal origin are the main sources for their transmission [67]. Poultry [66], pigs and cattle [72], 
and their products like meat, eggs $[4,73]$, and milk [74] are most commonly identified as food sources responsible for outbreaks of human salmonellosis although the microorganism has also been found in other foodstuff [4]. Chicken products including eggs are widely acknowledged to be a significant reservoir for Salmonella and have been consistently implicated in sporadic cases and the outbreak of human salmonellosis [64].

Consumption of raw or unsafe food, cross-contamination, improper food storage, poor personal hygiene practices, inadequate cooling and reheating of food items, and a prolonged time lapse between preparing and consuming food items were mentioned as contributing factors to an outbreak of salmonellosis in humans [12].

The bacteria enter the food chain at any point in livestock feed, and in food manufacturing, processing, retailing, catering, and preparation, survive typical catering refrigeration temperatures, and increase in number under conditions of thermal abuse [70]. Antibiotic-resistant salmonella infections of both humans and animals are universal concerns, particularly in developing countries, where the risk of infection is high because of unhygienic living conditions, close contact and sharing of houses between animals and humans, and the traditions of consumption of raw or undercooked animal-origin food items [12].

Studies conducted in different parts of Ethiopia have confirmed the presence of Salmonella in human beings, different food animals, and food of animal origin. Despite there are reports on prevalence and distribution of Salmonella species in the country, the problem of these pathogens in food of animal origin is still not well known. Moreover, the risk factors associated with the contamination of animal products are not described, and incidence of food-borne salmonellosis is still unknown in the country $[12,70]$. Occurrence of carrier food animals, illegal slaughtering of animals in open fields, unhygienic slaughter practices in the abattoirs, and widespread tradition of consumption of raw meat are potential risk factors of salmonella infection in the country [27]. Few published findings on prevalence of nontyphoidal Salmonella in different parts of Ethiopia are given in Table 2.

(3) Transmission. Food-borne transmission is recognized as the major cause of salmonella infections [12]. Animal-origin food and their products are the commonest vehicles of Salmonella to humans [64]. However, transmission also occurs by ingestion of water, food contaminated with animal faeces, and contaminated food-processing equipment [3]. The nontyphoidal Salmonella serovars are predominantly associated with food of animal origin such as milk, eggs, poultry, beef, and pork [69].

Contaminated animal products usually result from infected animals used in food production or from contamination of the carcasses or edible organs. Crosscontamination of carcasses with Salmonella can also occur during slaughtering operations [83]. Eggshells and egg contents can be contaminated by this bacterium during egg formation in the hen reproductive system or from the environment including fecal contact [74]. Fecal or intestinal contamination of carcasses is the principal source of human food-borne infections. The exception is when Salmonella is directly transmitted into the food product [67]. The recently emerged S. typhimurium DT104, a multidrug-resistant definitive type, is mainly transmitted through ingestion of contaminated beef [3].

(4) Pathogenesis. Factors such as strain virulence, infectious dose, route of infection, and host susceptibility mediate the pathogenicity of the organism. Virulence factors such as virulence plasmids, toxins, fimbriae, and flagella help in establishing an infection [64]. The complex invasion process is mediated by the product of a number of chromosomal genes, whereas growth within the host cell depends on the presence of virulence plasmids [8]. Microfold (M) cells are the target cells of Salmonella pathogenicity. Some of the mechanisms of pathogenesis are bacterial-mediated endocytosis, neutrophil recruitment and migration, epithelial cell cytokine secretion, fluid and electrolyte secretion, and systemic infection [64].

Normal flora protects against colonization and administration of oral antibiotics facilitates establishment of infection [8]. Salmonella avoid host defense in the stomach, reach the intestines, and interact with the nonphagocytic cells such as the epithelial cells of the intestinal mucosa. They adhere to the intestinal epithelial cells by fimbriae (adhesive structures) that promote binding and invade epithelial cells to provoke gastroenteritis [64].

Enteric infection is characterized by local damage without septicemia-salmonella infection with microfold cells in Peyer's patches which is facilitated by fimbrial adhesions. This is followed by ruffling of the target cell membrane which results in internalization of the bacteria in membranebound vacuoles. The ruffles facilitate uptake of the bacteria in membrane-bound vacuoles or vesicles which often coalesce [8].

(5) Symptoms. The incubation period ranges from 12 to $72 \mathrm{hrs} \mathrm{[3].} \mathrm{The} \mathrm{clinical} \mathrm{manifestation} \mathrm{of} \mathrm{salmonella} \mathrm{infection}$ ranges in severity from self-limiting gastroenteritis to septicemia. The severity of disease depends heavily on the host susceptibility and the virulence of the serovar [64].

Symptoms are usually gastrointestinal including nausea, vomiting, abdominal cramps, and watery, greenish, and foul-smelling diarrhea or bloody diarrhea with mucous. Other findings include headache, prostration, fatigue (muscle weakness), and moderate fever [8]. The disease is of self-limiting nature and does not require specific treatments but can result in serious complication in young children, old, and immunocompromised individuals [3]. Reactive arthritis, sickle-cell anemia, and osteomyelitis due to salmonella infection are much more common in the general population [8].

(6) Detection. Salmonella surveillance and monitoring should be based on reliable and efficient detection methods, which should help improve food safety. Commercially available rapid methods for Salmonella detection can be divided into several categories including new selective 
Table 2: Prevalence of zoonotic nontyphoidal Salmonella in different regions of Ethiopia.

\begin{tabular}{lccc}
\hline Sample type & No. of examined & No. of positive (prevalence) & Source \\
\hline Mutton & 200 & $3(1.5)$ & \\
Chevon & 184 & $1(0.54)$ & Kassaye et al. [71]; Addis Ababa Abattoirs Enterprise \\
Total & 384 & $4(1.04)$ & \\
Cheese & 96 & $3(3.1)$ & Liyuwork et al. [75]; Addis Ababa \\
Yogurt & 96 & $0(0)$ & \\
Butter & 96 & $1(1.04)$ & \\
Milk & 96 & $2(2.1)$ & Taddese et al. [74]; Jimma town \\
Total & $\mathbf{3 8 4}$ & $\mathbf{6}(\mathbf{1 . 6 )}$ & \\
\hline Eggshell & 166 & $4(2.4)$ & Molla et al. [76]; Debre Zeyit and Addis Ababa \\
Egg content & 166 & $\mathbf{5}(3.01)$ & \\
Total & $\mathbf{9 3 2}$ & $80(21.1)$ & Ejeta et al. [77]; Addis Ababa \\
\hline Chicken carcass and giblets & 378 & $23(14.4)$ & \\
Minced beef & 160 & $12(14.1)$ & \\
Mutton & 85 & $9(16.4)$ & Wabeto et al. [78]; Wolaita Sodo \\
Pork & 55 & $\mathbf{4 4}(\mathbf{1 4 . 7})$ & Mulaw [79]; Bahir Dar town \\
Total & $\mathbf{3 0 0}$ & $56(12.5)$ & Atsbha et al. [80]; Mekelle city \\
Raw beef & 448 & $36(9.35)$ & Muluneh and Kibret [81]; Bahir Dar town \\
Raw cow milk & 384 & $7(7.29)$ & Abunna et al. [82]; Modjo town \\
Cattle carcass & 96 & $23(7.6)$ &
\end{tabular}

media, modified or adapted conventional procedures, immunology-based assays, and nucleic acid-based assays [84].

In general, culturing and isolation of bacteria using selective enrichment media such as Salmonella Shigella agar, Hektoen enteric agar, or deoxycholate agar and broth for enrichment are usual procedures [8].

Serotyping has wide acceptance as a method to differentiate Salmonella strains, and it is an important tool in public health [67]. Immunology-based methods involving antigen-antibody bindings have been widely used for the detection of food-borne pathogens [85]. The immunologybased assays include ELISA, latex agglutination tests, immunodiffusion, and immunochromatography (dipstick). Moreover, direct hybridization (DNA probe) and amplification (PCR) methods are the two major techniques of the molecular assays that are used for the detection of Salmonella pathogens [84].

(7) Prevention and Control. Instituting biosecurity and biocontainment practices in addition to enhanced food processing method and preparation and storage practices are required to control and prevent food spoilage due to Salmonella [8]. Attenuated DNA recombinant live Salmonella vaccines combined with comprehensive control strategy in animals, feed, and animal foodstuff will help to reduce salmonellosis [64].

Safe food preparation practices including through cooking, reheating of food, pasteurization (boiling) of milk, adequate refrigeration, and exclusion of pets and other animals from food-handling areas should be carried out [8].

Additional measures to control secondary contamination could be prevention of contamination by cleaning and disinfection, hygiene of personnel, and proper processing [64]. Vulnerable groups are advised to avoid consuming undercooked meat and poultry, raw milk, eggs, and foods that contain raw egg [8].

2.2.3. Campylobacter. Campylobacter was first reported in 1886 by Theodore Escherich who observed and described nonculturable spiral-shaped bacteria [86]. The genus Campylobacter is of great importance in human medicine and food safety, in addition to its veterinary importance [87]. Campylobacter species are the leading cause of bacterialderived food-borne diarrheal disease in humans worldwide [88], resulting mainly from the contamination of food of animal origin $[89,90]$. Campylobacter can colonize in most of the warm-blooded animals and poultry [91].

The zoonotic nature of campylobacteriosis makes it important from clinical and economic perspectives worldwide [92]. They are responsible for $15 \%$ of food-borne illness-related hospitalizations and $6 \%$ of food-borne illnessrelated deaths [8], and an estimated 400 million cases are reported per year due to Campylobacter infection [93, 94]. The economic losses due to Campylobacter infections are mainly related to treatment costs, loss of productivity for infected people, and costs for controlling the pathogen [92].

(1) Etiology. The word Campylobacter is derived from two Greece words "campylos" meaning curved and "baktron" meaning rod [93]. Campylobacter is a member of the family Campylobacteriaceae, which also includes the genera Arcobacter and the species Bacteroides ureolyticus [4]. The genus Campylobacter contains small (0.2-0.8 $\mu \mathrm{m} \times 0.5-5 \mu \mathrm{m})$ [86], Gram-negative, curved, or spiral and microaerophilic bacteria [3, 91, 93, 95] with a distinctive "darting" motility, and they are catalase- and oxidase-positive $[89,90]$. When two or more bacterial 
cells are grouped together, they form an "S" or a "V" shape of the gull wing [86].

The genus Campylobacter currently comprises 25 species and 8 subspecies [93]. Among these Campylobacter species, thermophilic Campylobacter species, particularly C. jejuni and C. coli, are important food-borne pathogens [3]. C. jejuni is the major frequently reported Campylobacter species ( $80 \%$ to $90 \%$ ) followed by C. coli (5\% to $10 \%$ ) [93].

(2) Epidemiology. Campylobacter species are the leading cause of human and animal bacterial diarrheal disease worldwide [89], and they are common problems both in developing and industrialized countries of world [91].

They are found ubiquitous in the environment, and many species act as reservoirs or are susceptible, and wild birds are known to be natural hosts $[93,96]$. Campylobacter outbreaks are sporadic in nature and are not associated with mortality but can result in secondary complications [3].

These organisms are widely distributed in nature and are mainly recognized as zoonotic infections in a multitude of animal reservoirs, particularly avian species, with shedding into the environment [90]. They are known to colonize the alimentary tract of wild and domesticated birds and mammals, including all food-producing animals [97]. Campylobacter can be found in the reproductive organs, intestinal tracts, and oral cavity of animals and humans [89].

$100 \%$ of poultry (including chickens, turkeys, and waterfowl) [8], cattle, sheep, pigs, and other food animals [86, 87, 98], as well as wild animals and birds [93], are reservoirs of Campylobacter, and they harbor high levels of strain diversity. Companion animals including cats and dogs also carry Campylobacter species [96], and rodents may act as reservoirs [87]. Poultry is generally considered to be the most important reservoir for Campylobacter species [3, 94]. However, table eggs are not considered as an important source of the organism [3]. Organisms can be found in bulk milk samples, tissue specimens from beef cattle, and raw ground beef [87].

A large and diverse number of risk factors contribute to the susceptibility of humans to campylobacteriosis. Traveling is the most important risk factor followed by consumption of undercooked chicken, environmental exposure, and direct contact with farm animals [99]. In Ethiopia, few studies are conducted in the central part of the country to estimate the prevalence of Campylobacter species in food of animal origin, and some of the published findings are described in Table 3.

(3) Transmission. Transmission can occur through direct contact with infected animals or from equipment, water, or during carcass dressing in a slaughter line [100]. The main transmission route of Campylobacter to humans is handling, preparation, and consumption of contaminated food, especially of poultry origin $[88,95]$. Animal food products are most commonly contaminated by this pathogen during slaughter and carcass dressing [94] or indirect fecal contamination $[98,101]$.

Infections occur mainly from consumption of contaminated poultry [94], beef, and pork [9] or other animal meat, meat products, raw (unpasteurized) milk, and/or milk products like cheese $[3,89,90,93]$. Cross-contamination of ready-to-eat food during preparation by food handlers as well as direct contact with animals have also been identified [89]. Around $30 \%$ of all cases of infection were caused by the consumption of poultry, $20-30 \%$ of cases caused by pathogens from cattle, and a low percentage of pathogenic strains originating from other sources, including game [9].

(4) Pathogenesis. The pathogenesis of campylobacteriosis is not fully understood [101]. Though it is not fully understood, several mechanisms are hypothesized which are responsible for pathogenesis of Campylobacter infection [95]. Bacterial motility, mucus colonization, epithelial cell invasion, toxin production, attachment, internalization, and translocation play an important role in the disease development associated with C. jejuni virulence $[8,95]$.

The flagellum which has a coded flagellin gene (flaA) enables the bacterium to reach the attachment sites in the intestine. Several putative virulence factors have been identified in Campylobacter which contribute to the motility, intestinal adhesion, colonization, toxin production, and invasion. Adhesion of the pathogen to the intestinal epithelium is important for colonization and to increase the secretion of bacterial toxins [101]. The bacteria produce several cytotoxins that contribute to the development of the disease. Furthermore, C. jejuni is able to produce superoxide dismutase enzyme which catalyzes the breakdown of superoxide radicals, and it is one of the bacterial major defense mechanisms against oxidative damage $[19,142]$.

The organism upon consumption multiplies in the intestinal tract and damages the mucosal epithelium, resulting in self-limiting diarrhea and abdominal pain [3]. C. jejuni invades both epithelial cells and cells within the lamina propria [8]. The diarrheal disease may be due to the production of a heat-liable toxin [101].

(5) Symptoms. The incubation period varies from 3 to 5 days [3]. In humans, campylobacteriosis is characterized by watery and/or bloody diarrhea, abdominal pain, cramps, fever, malaise, and vomiting [4, 95]. This is especially dangerous for young children who are more prone to dehydration and loss of nutrients, such as sodium and protein, as a consequence of the diarrheal illness [95]. The pathogen is also the main causative agent of "traveler diarrhea." [93] Toxic megacolon, dehydration, and sepsis may occur especially in the young ( $<1$ year of age) and immune-compromised patients [102].

The most important postinfectious complication of Campylobacter infection is Guillain-Barre syndrome (GBS) [87], about 2-4 weeks after infection [8], which is characterized by polyneuritis of the peripheral nerves that may lead to either short-term or lengthy paralysis of the limbs which lasts for several weeks $[90,101,102]$. Other complications can include meningitis, urinary tract infections, and shortterm reactive arthritis [8].

(6) Detection. Identification methods for Campylobacter have traditionally involved the use of selective culture media 
TABle 3: Prevalence of Campylobacter species in food of animal origin in different parts of Ethiopia.

\begin{tabular}{|c|c|c|c|c|c|}
\hline \multirow{2}{*}{ Sample type } & \multirow{2}{*}{ No. of examined } & \multicolumn{3}{|c|}{ Number of positive (prevalence) } & \multirow{2}{*}{ Source } \\
\hline & & C. jejuni & C. coli & Total & \\
\hline Sheep carcass & 218 & $17(7)$ & $6(2.8)$ & $23(10.6)$ & \multirow{3}{*}{ Woldemariam et al. [87]; Debre Zeyit area, Ethiopia } \\
\hline Goat carcass & 180 & $12(6.7)$ & $5(2.8)$ & $17(9.4)$ & \\
\hline Total & 398 & $29(7.3)$ & $11(2.76)$ & $40(10)$ & \\
\hline Beef & 227 & $12(5.3)$ & $2(0.9)$ & $14(6.2)$ & \multirow{6}{*}{ Dadi and Asrat [89]; Addis Ababa and Debre Zeyit } \\
\hline Mutton & 114 & $10(8.8)$ & $2(1.7)$ & $12(10.5)$ & \\
\hline Chevon & 92 & $5(5.4)$ & $2(2.2)$ & $7(7.6)$ & \\
\hline Pork & 47 & $1(2.1)$ & $2(4.3)$ & $3(6.4)$ & \\
\hline Chicken & 60 & $11(18.3)$ & $1(1.7)$ & $12(20)$ & \\
\hline Total & 540 & $39(7.2)$ & $9(1.7)$ & $48(8.9)$ & \\
\hline Beef & 384 & $28(7.3)$ & $8(2.1)$ & $36(9.4)$ & Faris [28]; Addis Ababa \\
\hline Carcass swab (mutton) & 70 & $14(20)$ & $1(1.4)$ & $15(21.4)$ & Chanyalew et al. [100]; Debre Birhan \\
\hline
\end{tabular}

combined with biochemical tests. Recently, PCR has increasingly been applied in the detection and identification of Campylobacter [103].

Recently, campylobacteriosis may be diagnosed using conventional and molecular techniques. Bacterial culture is frequently used for routine isolation, and biochemical tests are used for phenotypic identification of Campylobacter [92]. Several of the selective broths, e.g., Bolton broth, Campylobacter enrichment broth, and Preston broth, have been compared for their efficacy. Several selective agars have been formulated and tested for their efficacy in isolating Campylobacter. For example, Preston, charchoal-cefoperazone-deoxycholate, and Butzler agars have been found to be equally effective [86].

As an alternative to growth on agar and biochemical identification methods, a variety of technologies including immunoassay methods and molecular techniques (PCR) can be used [101].

(7) Control and Prevention. Control depends on sanitation and hygiene in livestock barns to reduce the bacterial populations in the environment of the animals. The number of organisms can be reduced and controlled in meat-processing plants by using HACCP including washing, handling, and freezing of carcasses. Improvement of foodhandling skills in restaurants and in home kitchen will reduce transmission of the organism, and adequate cooking of raw meat such as poultry to an internal temperature of $82^{\circ} \mathrm{C}$ will eliminate the organism [8].

Biosecurity measures and personal hygiene practices are the main approaches needed to be considered to control campylobacteriosis. Essential oils, prebiotics, probiotics, bacteriocins, bacteriophages, and immunization measures also have a significant role to control Campylobacter [99].

2.2.4. Listeria monocytogenes. L. monocytogenes is a foodborne pathogen widely distributed in nature [104]. It is an important cause of diseases in both animals and humans [105]. It is one of the most virulent pathogens that controlling and monitoring agencies across the globe have been trying to contain [106], which is associated with the highest case fatality rate of $30 \%$ approximately, unlike infection with other common food-borne pathogens [107].

It is a major food-borne zoonotic bacterium of serious public health concern $[106,108,109]$ following consumption of contaminated food of animal origin [110]. L. monocytogenes emergence as a food-borne pathogen dates from 1980, with the occurrence of many outbreaks and sporadic cases of listeriosis associated with the consumption of contaminated food [111].

Moreover, the presence of L. monocytogenes in food has important economic consequences, such as the withdrawal of products from the consumer marketplace and a decrease in sales of the incriminated products [112]. Due to ubiquitous nature of Listeria species and their unique ability to survive across a broad range of environmental stress including $\mathrm{pH}$, temperature, and salt, they are considered as important food-borne pathogens [113].

(1) Etiology. The organisms of genus Listeria are psychotropic, Gram-positive, motile, facultative anaerobic, nonspore forming, and rod-shaped bacteria [111, 112, 114, 115]. L. monocytogenes, L. ivanovii, L. innocua, L. welshimeri, $L$. seeligeri, L. grayi, L. murrayi, L. marthii, L. fleischmannii, and L. weihenstephanensis are ten species of genus Listeria [116].

Although genus Listeria currently comprises 10 species, human cases of listeriosis are caused almost exclusively by the species L. monocytogenes $[117,118]$. L. monocytogenes is the principal pathogen in humans and animals [116]. The bacterium is capable of surviving under refrigeration conditions, low $\mathrm{pH}$, and in high salt concentration [3]. It is a facultative intracellular bacterium that is able to grow in temperatures between 0 and $45^{\circ} \mathrm{C}$, that supports $\mathrm{pH}$ between 4.4 and 9.4, and that requires minimum water activity of 0.92 [119].

(2) Epidemiology. The occurrence of L. monocytogenes is worldwide [112]. Listeriosis occurs in a sporadic or epidemic form throughout the world [120].

Genus Listeria contains ubiquitous bacteria that are extensively disseminated in normal environments $[106,117,118]$. Listeria species are most commonly found in 
raw food, vegetables contaminated by soil- and water-carrying bacteria, and raw animal products [109, 121].

Even though pasteurization of raw milk destroys L. monocytogenes, this process does not eliminate the later risk of contamination of dairy products $[115,122]$.

L. monocytogenes is frequently isolated from food of animal origin such as ready-to-eat meat products, ground beef $[111,115]$, meat and meat products (sausages) $[3,33]$, fish and fish products [114], milk, and pasteurized dairy products like soft cheese and ice cream [107, 121].

Human acquisition of listeriosis from animal sources has been shown to occur as an occupational hazard especially in farmers, butchers, poultry workers, and veterinary surgeons $[115,122]$. The major risk population groups at risk for invasive listeriosis are the immunocompromised hosts such as pregnant women, unborn or newly delivered infants, organ transplant recipients, cancer and acquired immune deficiency syndrome (AIDS) patients, and the elderly [115].

In Ethiopia, published information occurrence and distribution of L. monocytogenes and food-borne listeriosis is very limited both in veterinary and public health sectors $[107,108,110]$. Some of the published information on the prevalence of L. monocytogenes in food of animal origin in different regions of Ethiopia is described in Table 4.

(3) Transmission. The most common route of infection in humans is consumption of food of animal origin contaminated by L. monocytogenes $[115,116,118,120,124,125]$. The risk of infection is higher in pregnant women, newborns, older people, and immunocompromised people [3].

(4) Pathogenesis. Listeria possesses unique virulence factors to invade host, evade immune cells, and cause infection [120]. L. monocytogenes has D-galactose residues on its surface that can attach to D-galactose receptors on the host cell. These host cells are generally M cells and Payer's patches of the intestinal mucosa. Once attached to these cells, $L$. monocytogenes can cross the intestinal membrane and enter to bloodstream. The bacterium becomes a blood-borne (septicemic), and it can grow after it enters into host's monocytes, macrophages, or polymorphonuclear leukocytes [8].

Since it is an intracellular bacterium, it has the capability to infect a wide range of cell types, cross barriers (intestinal, blood-brain, and placental barriers) and cause infections [113].

(5) Symptoms. The symptoms of listeriosis usually last 7-10 days [8]. L. monocytogenes generally presents itself with typical "food poisoning" symptoms [126]. Infection is characterized by flu-like symptoms such as fever, fatigue, and gastrointestinal symptoms (nausea, vomiting, and diarrhea) [106, 120, 121].

It can cause severe life-threatening infections such as septicemia, meningitis, meningoencephalitis, spontaneous abortion, still birth, or fetal infection in high-risk groups $[117,126,127]$. The disease is characterized by high mortality rate in affected individuals, and deaths due to listeriosis in human population increased in the $21^{\text {st }}$ century [3].
(6) Detection. The methods include enrichment in selective media, subsequent plating on agar plates, and various tests for species identification [128]. Enrichment procedures are required for this organism [8]. The two-stage enrichment method for detection of L. monocytogenes with isolation on polymyxin acriflavin lithium-chloride Ceftazidime aesculin mannitol (PALCAM) agar and Oxford agar is widely used. The Christie-Atkinson-Munch-Peterson (CAMP) reaction is useful for identifying Listeria species. This test uses horse blood agar and streaks off hemolytic S. aureus and Rhodococcus equi in combination with Listeria isolates. As molecular methods are accurate, sensitive, and specific, they are increasingly used in identification of L. monocytogenes from food [111].

Among molecular methods, PCR and RT-PCR are now established methods for identification of L. monocytogenes from other nonvirulent Listeria species from food [104, 111]. Using monoclonal antibodies, ELISA has been developed to identify Listeria in food [8].

(7) Control and Prevention. Preventing listeriosis can be done by carrying out an effective sanitation of food contact surfaces [8]. Food-safety control measures must be implemented properly to limit listeriosis and to ensure consistent control strategies. Good hygiene, GMP, and sanitation are the most appropriate strategies in operating procedures [120]. Vulnerable individuals (pregnant women, the elderly, and the immune-suppressed) are advised to avoid consuming unpasteurized dairy products to reduce the risk [111].

Standardized legal regulations and control of meat product manufacture should be a fundamental way to protect food from L. monocytogenes contamination. One of the most important ways to protect food from these microorganisms is to prevent the spread of the bacteria at processing plants at different stages of the food production chain [129].

The implementation of HACCP approach and the establishment of effective critical control points can significantly reduce the level of Listeria contamination in many processed food products. Standards/legislation for the pasteurization of ice cream/frozen desserts adapted in various countries have an importance in reducing listeriosis [111].

2.2.5. Escherichia coli. E. coli is among many pathogenic microorganisms which can get access to food of animal origin and is considered as a reliable indicator of contamination by manure, soil, and contaminated water [23]. An emerging clonally distinct form of $E$. coli was first identified as a significant food-borne zoonotic pathogen in 1982 when it was associated with an outbreak in the USA of severe bloody diarrhea that was traced to the consumption of undercooked hamburgers [130].

Most of E. coli are normal inhabitants of the gastrointestinal tract (lower ileum and large intestine) of animals and humans $[23,131,132]$, while others are pathogenic to humans [133]. E. coli are of zoonotic in nature and constitute a public health hazard [134]. Shiga toxin-producing E. coli 
TABle 4: Prevalence of L. monocytogenes in food of animal origin in different areas of Ethiopia.

\begin{tabular}{|c|c|c|c|}
\hline Sample type & No. of examined & No. of positive (prevalence) & Source \\
\hline Mutton swab & 768 & $29(3.8)$ & \multirow{5}{*}{ Mulu and Pal [107]; Addis Ababa } \\
\hline Cutting table & 45 & $4(8.9)$ & \\
\hline Hook & 20 & $0(0)$ & \\
\hline Knife & 40 & $3(7.5)$ & \\
\hline Total & 873 & $36(4.1)$ & \\
\hline Raw meat & 60 & $4(6.6)$ & \multirow{10}{*}{ Garedew et al. [110]; Gondar town } \\
\hline Minced beef & 25 & $3(12)$ & \\
\hline Fish meat & 50 & $3(6)$ & \\
\hline Pizza & 24 & $2(8.3)$ & \\
\hline Pasteurized milk & 50 & $0(0)$ & \\
\hline Raw milk & 50 & $2(4)$ & \\
\hline Cottage cheese & 40 & $0(0)$ & \\
\hline Ice cream & 20 & $3(15)$ & \\
\hline Cream cakes & 65 & $7(10.7)$ & \\
\hline Total & 384 & $24(6.25)$ & \\
\hline Raw meat & - & $4 / 59(6.8)$ & \multirow{5}{*}{ Derra et al. [105]; area of Addis Ababa } \\
\hline Raw milk & - & $2 / 59(3.4)$ & \\
\hline Cottage cheese & - & $1 / 59(1.7)$ & \\
\hline Cream cake & - & $3 / 59(5.1)$ & \\
\hline Total & 240 & $10(4.1)$ & \\
\hline Cottage cheese & 100 & $1(1)$ & \multirow{5}{*}{ Gebretsadik et al. [123]; Addis Ababa } \\
\hline Raw beef & 76 & $2(2.6)$ & \\
\hline Raw milk & 100 & $13(13)$ & \\
\hline Liquid whole egg & 115 & $5(4.3)$ & \\
\hline Total & 391 & $21(5.4)$ & \\
\hline Minced beef & 61 & $1(1.63)$ & \multirow{7}{*}{ Molla et al. [108]; Addis Ababa } \\
\hline Chicken & 52 & $1(1.9)$ & \\
\hline Fish & 43 & $1(2.3)$ & \\
\hline Pork & 53 & $4(7.5)$ & \\
\hline Cottage cheese & 61 & $0(0)$ & \\
\hline Ice cream & 46 & $9(19.6)$ & \\
\hline Total & 316 & $16(5.1)$ & \\
\hline Raw milk & 343 & $7(2.04)$ & \multirow{5}{*}{ Seyoum et al. [122]; Central Highlands of Ethiopia } \\
\hline Pasteurized milk & 65 & $13(20)$ & \\
\hline Yogurt & 20 & $1(5)$ & \\
\hline Cheese & 15 & $4(26.7)$ & \\
\hline Total & 443 & $25(5.6)$ & \\
\hline
\end{tabular}

were associated with several life-threatening food-borne outbreaks worldwide [37].

(1) Etiology. E. coli is characterized as a Gram-negative, rodshaped bacterium belonging to the family Enterobacteriaceae with five virulence groups, including enteroaggregative E. coli, enterohemorrhagic E. coli, enteroinvasive E. coli, enteropathogenic E. coli, and enterotoxigenic E. coli [27]. They are rod-shaped bacteria up to $3 \mu \mathrm{m}$ in length and can ferment glucose and other sugars. They are motile with peritrichous flagella and often fimbriated [8].

E. coli $\mathrm{O} 157: \mathrm{H7}$ is one of the best known serotypes to contain pathotypes that can cause food-borne infection in humans $[17,27,35,133]$. It is a well-known Shiga toxinproducing bacterium $[29,135]$, and it is a major food-borne and zoonotic pathogen [132].

(2) Epidemiology. E. coli $\mathrm{O} 157: \mathrm{H} 7$ is one of the most important food-borne pathogens [136, 137]. E. coli O157:H7 has been reported increasingly from all parts of the world [17]. This strain is an important emerging food-borne pathogen of humans causing outbreaks worldwide $[3,138]$. Outbreaks have been reported from different countries of the world including the United States, Canada, Asia, Australia, Europe [23], and different African countries, stretching from South to East and West parts of the continent [131]. It has been indicated that an estimated 74,000 cases and 61 deaths annually are attributable to $E$. coli O157:H7 in the USA [17].

E. coli is a normal part of the intestinal microflora of many healthy animals, including humans. However, some strains can cause diseases [136]. Cattle are the major reservoirs of E. coli O157:H7 [3, 8, 131, 133, 139] followed by sheep and goats [137]. The role of small ruminants as a source of human infection through fecal shedding is being reported in a number of studies [131]. The organisms are also isolated from horses, dogs, and deer [3]. Milk and milk products [134], poorly cooked beef, tainted ground beef, and other bovine food products are identified as major sources of infection in outbreaks [139, 140]. 
The rising incidence and potentially serious nature of $E$. coli O157:H7 infection are a cause for concern to public health authorities [131]. The major contributing factors of $E$. coli O157:H7 infection are changes in eating habits, mass catering, complex and lengthy food-supply procedures with increased international movement, and poor hygiene practices [29].

Epidemiology of food-borne pathogens especially that of E. coli O157:H7 was not well studied in Ethiopia in the past years [135]. According to Abreham et al. [131], the data on the prevalence, virulence, and gene diversity in ruminants and food of animal origin in Ethiopia are still limited. However, recently, there is an increasing trend of reporting occurrence level of the organism in beef and dairy products [135]. Though most of the studies were conducted in central Ethiopia, studies have been carried out to estimate the occurrence of $E$. coli in food of animal origin, mainly in meat and milk in recent years. Some of the published findings are described in Table 5 .

(3) Transmission. The most frequent mode of transmission for E. coli $\mathrm{O} 157: \mathrm{H} 7$ infection to humans is through consumption of contaminated food and water and may also spread directly from person to person and occasionally through occupational exposure [133]. E. coli are food-borne zoonosis transmitted through the consumption of contaminated food of animal origin [134]. The most common means of transmission of $E$. coli $\mathrm{O} 157: \mathrm{H7}$ to humans is through consumption of raw or undercooked meat of bovine origin [131, 133, 136, 137]. Transmission may occur through consumption of contaminated raw milk $[3,35]$ and unpasteurized dairy products [132]. Nevertheless, varieties of other food items have also been implicated in causing outbreaks [131].

Carcass contamination occurs through skin-to-carcass or fecal-to-carcass transfer of the pathogen during slaughter process at processing plants which is the major risk factor for human infection. Furthermore, cross-contamination can occur during further processing of carcasses in the processing plants, during distribution and storage of beef at retail markets [139].

(4) Pathogenesis. Virulence factors, Shiga-like toxin, and adherence factors are the mechanisms of bacterial pathogenicity [142]. Intimin gene is responsible for the bacteria's intimate adhesion to intestinal cells, causing the appearance of attachment lesions and erasure of the microvilli of the brush border of enterocytes [131]. E. coli consists of the destruction of microvilli, intimate effacing adherence of the organism to the enterocyte membrane, and changes in the cytoskeletal structure of the enterocyte associated with the accumulation of polymerized actin and other cytoskeletal proteins beneath the site of bacterial attachment [143].

The adhesive structures may be fimbrial or nonfimbrial, which would mediate the process of binding and colonization. Adhesive factors may lead to bacterial colonization, proliferation, and pathogenesis. E. coli O157:H7 can adhere to intestinal mucosal tissues and secrete several proteins, enzymes, and toxins [142]. The production of Shiga toxin is central to the pathogenesis of bloody diarrhea and haemolytic uraemic syndrome. E. coli O157:H7 strain produces Shiga toxin 1 (stx-1) and Shiga toxin 2 (stx-2) [138].

The toxins provoke cell secretion and kill colonic epithelial cells. In animals, the toxin has been shown to cause localized fluid accumulation and colonic lesion characterized by sloughing of the surface and crypt epithelial cells [8].

(5) Symptoms. The incubation period ranges between 2 and 10 days followed by appearance of diarrhea, abdominal pain, vomiting, hemorrhagic colitis, haemolytic uraemic syndrome with acute kidney failure, and thrombotic thrombocytopenic purpura $[3,137]$. The clinical sign initially may be diarrhea with abdominal cramps, which may turn into grossly bloody diarrhea in a few days. However, there is no fever. Septicemia starts with bacteremia and ends with toxemia, and its severity depends on the effect of bacteria localization in a variety of tissue spaces throughout the body [8].

(6) Detection. During outbreak investigations, surveillance, and quality control, employing sensitive methods to detect E. coli O157:H7 is suggested [131]. Different methods such as culture in special media, serological, and molecular assays have been used for detection of this serotype in food, environmental, and clinical samples [144].

Culture isolation of E. coli O157:H7 still is the gold standard for identification [142] assisted by biochemical tests [145]. Sorbitol-MacConkey agar (SMAC) supplemented with cefixime and potassium tellurite is one of the most sensitive and differential media to isolate E. coli O157: H7 from other serotypes of E. coli $[143,144]$. The SMAC agar consists of bile salts, a carbohydrate source, sorbitol, and an indicator. E. coli O157:H7 does not ferment sorbitol. If E. coli O157:H7 is present, colourless colonies will appear, while other Enterobacteriaceae will show up as pink colonies [145]. Their identity is confirmed by agglutination with specific antiserum [146].

Various immunoassay techniques [8], several rapid screening methods, and serological techniques may be helpful for specific diagnosis [143]. PCR-ELISA method, several qPCR methods, loop-mediated isothermal amplification (LAMP), and a magnetic microparticle are the main effective methods to detect Shiga toxins as reported by different scholars [142].

(7) Control and Prevention. The prevention/avoidance of food-borne illness caused by $E$. coli can be prevented by the same method as prevention of other food-borne diseases caused by bacteria. However, special precaution is required due to their severe consequences in young children [8].

Preharvest control of E. coli O157:H7 is a control strategy which improves human health, food and water safety, and cattle pathogen-reduction by good sanitation procedures during food preparation, practices, and transport management [142]. Another option in cattle is intervention methods such as probiotics, vaccination, antimicrobials, sodium chlorate, and bacteriophages which are important to increase herd resistance to infection and subsequent control of 
Table 5: Prevalence of E. coli in food of animal origin in different areas of Ethiopia.

\begin{tabular}{|c|c|c|c|c|}
\hline \multirow[t]{2}{*}{ Sample type } & \multirow[t]{2}{*}{ No. of examined } & \multicolumn{2}{|c|}{$\begin{array}{l}\text { Number of positive } \\
\text { (prevalence) }\end{array}$} & \multirow[t]{2}{*}{ Source } \\
\hline & & E. coli & E. coli $\mathrm{O} 157: \mathrm{H} 7$ & \\
\hline Beef & 113 & $35(30.97)$ & $3(2.65)$ & \multirow{5}{*}{ Bekele et al. [133]; Addis Ababa } \\
\hline Beef & 128 & - & $17(13.3)$ & \\
\hline Mutton & 128 & - & $12(9.4)$ & \\
\hline Chevon & 128 & & $10(7.8)$ & \\
\hline Total & 384 & - & $39(10.2 \%)$ & \\
\hline Raw cow milk & 380 & $129(33.9)$ & $11(2.9)$ & \multirow{7}{*}{ Bedasa et al. [17]; Bishoftu town, Central Ethiopia } \\
\hline Cheese & 35 & $14(40)$ & $2(5.71)$ & \\
\hline Raw milk & 25 & $8(32)$ & $3(12)$ & \\
\hline Pasteurized milk & 40 & $0(0)$ & $0(0)$ & \\
\hline Yogurt & 35 & $9(25.71)$ & $0(0)$ & \\
\hline Meat & 65 & $9(13.84)$ & $2(3.07)$ & \\
\hline Total & 200 & $40(20)$ & $7(3.5)$ & \\
\hline Beef & 250 & - & $20(8)$ & \multirow{4}{*}{ Hiko et al. [136]; Debre Zeyit and Modjo } \\
\hline Mutton & 243 & - & $6(2.5)$ & \\
\hline Chevon & 245 & - & $5(2)$ & \\
\hline Total & 738 & - & $31(4.2)$ & \\
\hline Carcass swab & 150 & - & $14(9.33)$ & Haile et al. [29]; Jimma town \\
\hline Carcass swab & 110 & - & $5(4.5)$ & \multirow{5}{*}{ Beyi et al. [141]; central Ethiopia } \\
\hline Cutting board swab & 110 & - & $4(3.6)$ & \\
\hline Fecal sample & 370 & - & $7(1.89)$ & \\
\hline Skin swab & 370 & - & $2(0.54)$ & \\
\hline Intestinal mucosal swab & 370 & - & $3(0.81)$ & \\
\hline Carcass internal swab & 370 & - & $2(0.54)$ & \multirow{4}{*}{ Abdissa et al. [139]; Addis Ababa and Debre Birhan cities } \\
\hline Carcass external swab & 370 & - & $0(0)$ & \\
\hline Environmental swabs & 62 & - & $0(0)$ & \\
\hline Cutting board & 125 & - & $1(0.8)$ & \\
\hline
\end{tabular}

E. coli O157:H7 [143]. Vaccination is an attractive strategy to reduce E. coli O157:H7 colonization [142].

Postharvest intervention technologies such as skin and carcass washing and the use of antimicrobials have been developed with varying success [139]. Food safety in the processing sector is based on HACCP approach. This approach is not specific to the control of E. coli but broadly addresses biological, chemical, and physical hazards. HACCP programs in the processing sector include microbial testing of the product for indicator bacteria and/or specifically for E. coli O157:H7. Interventions include the use of chemicals or antimicrobial products, knife trimming, vacuuming, washing, stream pasteurization, multiple hurdle interventions, gamma irradiation, low-dose low-penetrating radiation, and good manufacturing practices in the processing line. A systematic review of retail and consumer food-safety programs found evidence that food-handler training, food premise inspections, and community-based education programmes promoting proper food handling and preparation techniques are effective components in reducing public exposure to food-borne pathogens [143].

\section{Conclusion and Recommendations}

Food-borne zoonotic bacterial pathogens are the leading causes of human illness worldwide with a great burden in developing countries resulting in huge economic loss in addition to public health issues. S. aureus, Salmonella species, Campylobacter species, L. monocytogenes, and E. coli are the common bacterial pathogens which are associated with food of animal origin. These bacteria may enter into the food chain from production of food animals up to the final consumption of animal products. Currently, these bacterial pathogens have a great concern for public health due to the emergence of multidrug-resistant strains. Studies conducted in different parts of Ethiopia indicated that these zoonotic bacteria are commonly isolated from food of animal origin particularly in meat and dairy products. Despite there are reports on prevalence of food-borne zoonotic bacteria in food animals, food of animal origin, and humans, the burden of these pathogens in food of animal origin is still not well known, the associated risk factors are not clearly identified, and the incidence of human infections from zoonotic foodborne bacteria is not well documented as a majority of them are identified by conventional methods. Risk factors like the habit of raw animal product consumption, unstandardized slaughtering process, and nonhygienic food-preparation procedures and handling may prone people for food-borne zoonotic bacterial pathogens in the country.

Based on the above conclusion, the following recommendations are forwarded:

Coordinated surveillance and monitoring system for food-borne zoonotic bacterial pathogens should be done to design appropriate and effective control and prevention strategies against these pathogens in developing countries including Ethiopia 
The epidemiological information regarding to risk factors and incidence of human infections associated with food-borne zoonotic bacterial pathogens should be established and well documented at national level

(i) Good manufacturing practices, standardized slaughtering and pasteurization procedures, and hygienic animal product-preparation techniques should be properly implemented

(ii) Awareness to the public should be created associated with risk factors of food-borne zoonotic bacterial pathogens based on findings of different researchers

(iii) These bacterial pathogens should be characterized at molecular level, and possible prevention and control strategies should be developed

\section{Conflicts of Interest}

The authors declare that they have no conflicts of interest.

\section{References}

[1] CSA, "the federal democratic republic of ethiopia, central statistical agency," vol. 2Report on Livestock and Livestock Characteristics, Agricultiral Sample Survey 2017/2018 (2010 E.c), Statistical Bulletin 587, pp. 1-87, CSA, Ababa, Ethiopia, 2018.

[2] T. Eshetie, K. Hussien, T. Teshome, and A. Mekonnen, "Meat production, consumption and marketing tradeoffs and potentials in Ethiopia and its effect on GDP growth: a review," Journal of Nutritional Health \& Food Engineering, vol. 8, no. 3, pp. 228-233, 2018.

[3] K. Dhama, S. Rajagunalan, S. Chakraborty et al., "Food-borne pathogens of animal origin-diagnosis, prevention, control and their zoonotic significance: a review," Pakistan Journal of Biological Sciences, vol. 16, no. 20, pp. 1076-1085, 2013.

[4] N. Heredia and S. Garcia, "Animals as sources of food-borne pathogens: a review," Animal Nutrition, vol. 4, no. 3, pp. 250-255, 2018.

[5] V. B. Hemalata and D. B. M. Virupakshaiah, "Isolation and identification of food borne pathogens from spoiled food samples," International Journal of Current Microbiology and Applied Sciences, vol. 5, no. 6, pp. 1017-1025, 2016.

[6] A. Aklilu, D. Kahase, M. Dessalegn et al., "Prevalence of intestinal parasites, Salmonella and Shigella among apparently health food handlers of addis ababa university student's cafeteria, addis ababa, Ethiopia," BMC Research Notes, vol. 8, no. 1, p. 17, 2015.

[7] J. Kadariya, C. T. Smith, and D. Thapaliya, "Staphylococcus aureus and staphylococcal food-borne disease: an ongoing challenge in public health," BioMed Research International, vol. 2014, Article ID 827965, 9 pages, 2014.

[8] M. Addis and D. Sisay, "A review on major food borne bacterial illnesses," Journal of Tropical Diseases, vol. 3, no. 4, pp. 1-7, 2015.

[9] A. Chlebicz and K. Śliżewska, "Campylobacteriosis, salmonellosis, yersiniosis, and listeriosis as zoonotic foodborne diseases: a review," International Journal of Environmental Research and Public Health, vol. 15, no. 5, pp. 1-28, 2018.

[10] S. Bidaisee and C. N. L. Macpherson, "Zoonoses and one health: a review of the literature," Journal of Parasitology, vol. 2014, Article ID 874345, 8 pages, 2014.
[11] X. Zhao, C. Lin, J. Wang, and D. Oh, "Advances in rapid detection methods for foodborne pathogens," Journal of Microbiology and Biotechnology, vol. 24, no. 3, pp. 297-312, 2014.

[12] M. Ejo, L. Garedew, Z. Alebachew, and W. Worku, "Prevalence and antimicrobial resistance of Salmonella isolated from animal-origin food items in gondar, Ethiopia," BioMed Research International, vol. 2016, Article ID 4290506, 8 pages, 2016.

[13] M. Haileselassie, H. Taddele, K. Adhana, and S. Kalayou, "Food safety knowledge and practices of abattoir and butchery shops and the microbial profile of meat in mekelle city, Ethiopia," Asian Pacific Journal of Tropical Biomedicine, vol. 3, no. 5, pp. 407-412, 2013.

[14] M. Abebe, A. Hailelule, B. Abrha et al., "Antibiogram of Escherichia coli strains isolated from food of bovine origin in selected woredas of tigray, Ethiopia," African Journal of Microbiology Research, vol. 6, no. 3, pp. 17-22, 2014.

[15] A. Akbar and K. A. Kumar-Anal, "Food safety concerns and food-borne pathogens, Salmonella, Escherichia coli and Campylobacter," FUUAST Journal of Biology, vol. 1, no. 1, pp. 5-17, 2011.

[16] Z. Ayana, M. Yohannis, and Z. Abera, "Food-borne bacterial diseases in Ethiopia," Journal of the Academy of Nutrition and Dietetics, vol. 4, no. 1, pp. 62-76, 2015.

[17] S. Bedasa, D. Shiferaw, A. Abraha, and T. Moges, "Occurrence and antimicrobial susceptibility profile of Escherichia coli O157:H7 from food of animal origin in bishoftu town, Central Ethiopia," The International Journal of Food Contamination, vol. 5, no. 1, pp. 1-8, 2018.

[18] M. M. M. Guerra, de M. A. Almeida, and L. A. Willingham, "An overview of food safety and bacterial foodborne zoonoses in food production animals in the caribbean region," Tropical Animal Health and Production, vol. 48, no. 6, pp. 1095-1108, 2016.

[19] F. Abunna, T. Abriham, F. Gizaw et al., "Staphylococcus: isolation, identification and antimicrobial resistance in dairy cattle farms, municipal abattoir and personnel in and around asella, Ethiopia," Journal of Veterinary Science \& Technology, vol. 7, no. 6, pp. 1-7, 2016.

[20] K. Bantawa, K. Rai, S. D. Limbu, and H. Khanal, "Food-borne bacterial pathogens in marketed raw meat of dharan, eastern Nepal," BMC Research Notes, vol. 11, no. 1, pp. 1-5, 2018.

[21] R. Tsepo, L. Ngoma, M. Mwanza, and R. Ndou, "Prevalence and antibiotic resistance of Staphylococcus aureus isolated from beef carcasses at abattoirs in north west province," Journal of Human Ecology, vol. 56, pp. 188-195, 2016.

[22] N. M. Swartz, "Human diseases caused by foodborne pathogens of animal origin," Clinical Infectious Diseases, vol. 34, no. 3, pp. 111-122, 2002.

[23] N. Disassa, B. Sibhat, S. Mengistu, Y. Muktar, and D. Belina, "Prevalence and antimicrobial susceptibility pattern of E. coli O157:H7 isolated from traditionally marketed raw cow milk in and around asosa town, western Ethiopia," Veterinary Medicine International, vol. 2017, Article ID 7581531, 7 pages, 2017.

[24] T. Kebede, B. Afera, H. Taddele, and A. Bsrat, "Assessment of bacteriological quality of sold meat in the butcher shops of adigrat, tigray, Ethiopia bureau of agriculture and rural development," Applied Occupational and Enviromental Hygiene, vol. 3, no. 3, pp. 38-44, 2014.

[25] G. Abera, N. Kumar, T. Gebrewahd, and H. Yizengaw, "Study on assessment of community awareness towards common zoonotic diseases in and around asella, eastern arsi 
zone, Ethiopia," International Journal of Livestock Research, vol. 6, no. 5, pp. 83-90, 2016.

[26] H. Tassew, A. Abdissa, G. Beyene, and S. Gebre-Selassie, "Microbial flora and food borne pathogens on minced meat and their susceptibility to antimicrobial agents," Ethiopian Journal of Health Sciences, vol. 20, no. 3, pp. 137-143, 2011.

[27] A. Assefa and A. Bihon, "A systematic review and metaanalysis of prevalence of Escherichia coli in foods of animal origin in Ethiopia," Heliyon, vol. 4, no. 8, pp. 1-22, 2018.

[28] G. Faris, "Identification of Campylobacter species and their antibiotic resistance patterns from raw bovine meat in addis ababa, Ethiopia," International Journal of Multimedia Information Retrieval, vol. 4, no. 1, pp. 1-5, 2015.

[29] F. A. Haile, D. Kebede, and K. A. Wubshet, "Prevalence and antibiogram of Escherichia coli $\mathrm{O} 157$ isolated from bovine in jimma, Ethiopia: abattoirbased survey," Ethiopian Veterinary Journal, vol. 21, no. 2, pp. 109-120, 2017.

[30] S. Wu, N. Duan, H. Gu et al., "A review of the methods for detection of Staphylococcus aureus enterotoxins," Toxins, vol. 8, no. 7, pp. 1-20, 2016.

[31] S. Argaw and M. Addis, "A review on staphylococcal food poisoning," Food Science and Quality Management, vol. 40, pp. 59-71, 2015.

[32] A. Zelalem, M. Sisay, L. J. Vipham, K. Abegaz, A. Kebede, and Y. Terefe, "The prevalence and antimicrobial resistance profiles of bacterial isolates from meat and meat products in Ethiopia: a systematic review and meta-analysis," International Journal of Food Contamination, vol. 6, no. 1, pp. 1-14, 2019.

[33] J. J. Carrique-Mas and J. E. Bryant, "A review of foodborne bacterial and parasitic zoonoses in vietnam," EcoHealth, vol. 10, no. 4, pp. 465-489, 2013.

[34] E. Laslo and E. Gyorgy, "Evaluation of the microbiological quality of some dairy products," Acta Universitatis Sapientiae, Aliment, vol. 11, no. 1, pp. 27-44, 2019.

[35] S. A. Mustafa and L. A. Inanc, "Antibiotic resistance of Escherichia coli O157 : H7 isolated from chicken meats. Ksü tar," Doga Derg, vol. 21, no. 1, pp. 7-12, 2018.

[36] L. Y. Loir, F. Baron, and M. Gautier, "Staphylococcus aureus and food poisoning," Genetics and Molecular Research, vol. 2, no. 1, pp. 63-76, 2003.

[37] W. Elmonir, M. E. Abo-Remela, and A. Sobeih, "Public health risks of Escherichia coli and Staphylococcus aureus in raw bovine milk sold in informal markets in Egypt," Journal of Infection in Developing Countries, vol. 12, no. 7, pp. 533-541, 2018.

[38] K. M. Dehkordi, G. M. Shamsabadi, and P. Banimehdi, "The occurrence of Staphylococcus aureus, enterotoxigenic and methicillin-resistant strains in Iranian food resources: a systematic review and meta-analysis," Annali di Igiene, vol. 31, no. 3, pp. 263-278, 2019.

[39] D. Tessema and S. Tsegaye, "Study on the prevalence and distribution of Staphylococcus aureus in raw cow milk originated from alage atvet college dairy farm, Ethiopia," Journal of Nutrition \& Food Sciences, vol. 7, no. 2, pp. 2-5, 2017.

[40] C. Lozano, H. Gharsa, B. K. Slama, M. Zarazaga, and C. Torres, "Staphylococcus aureus in animals and food: Methicillin resistance, prevalence and population structure. A review in the african continent," Microorganisms, vol. 4, no. 1, pp. 1-19, 2016.

[41] D. Rodríguez-Lázaro, E. Oniciuc, G. P. García et al., "Detection and characterization of Staphylococcus aureus and methicillin-resistant $S$. aureus in foods confiscated in EU borders," Frontiers in Microbiology, vol. 8, pp. 1-10, 2017.

[42] W. Wang, Z. Baloch, T. Jiang et al., "Enterotoxigenicity and antimicrobial resistance of Staphylococcus aureus isolated from retail food in China," Frontiers in Microbiology, vol. 8, pp. 1-11, 2017.

[43] H. Abraha, G. Hadish, B. Aligaz, G. Eyas, and K. Workelule, "Antimicrobial resistance profile of Staphylococcus aureus isolated from raw cow milk and fresh fruit juice," Journal of Veterinary Medicine and Animal Health, vol. 10, no. 4, pp. 106-113, 2018.

[44] T. Beyene, H. Hayishe, F. Gizaw et al., "Prevalence and antimicrobial resistance profile of Staphylococcus in dairy farms, abattoir and humans in addis ababa, Ethiopia," BMC Research Notes, vol. 10, no. 1, pp. 1-9, 2017.

[45] J. EI-Jakee, S. A. Marouf, S. N. Ata et al., "Rapid method for detection of Staphylococcus aureus enterotoxins in food," Global Veterinarian, vol. 11, no. 3, pp. 335-341, 2013.

[46] A. Mardziah, C. C. Yeo, M. S. Puah, H. K. Chua, and H. C. Chew, "Staphylococcus aureus infections in Malaysia: a review of antimicrobial resistance and characteristics of the clinical isolates, 1990-2017," Antibiotics, vol. 8, pp. 1-29, 2019.

[47] B. Batabyal, G. K. R. Kundu, and S. Biswas, "Methicillinresistant Staphylococcus aureus: a brief review," International Research Journal of Biological Sciences, vol. 1, no. 7, pp. 65-71, 2012.

[48] S. Mohammed and S. Nigatu, "Review on livestock associated Methicillin resistant Staphylococcus aureus and its zoonotic importance," International Journal of Microbiology, vol. 6, no. 3, pp. 164-174, 2015.

[49] F. Tessema, "Review on the prevalence and drug resistance patterns of Staphylococcus aureus in food producing animals, their products and humans," International Journal of Bioscience and Medicine, vol. 1, no. 5, pp. 1-11, 2017.

[50] B. B. Asiimwe, R. Baldan, A. Trovato, and M. D. Cirillo, "Prevalence and molecular characteristics of Staphylococcus aureus, including Methicillin resistant strains, isolated from bulk can milk and raw milk products in pastoral communities of south-west Uganda," BMC Infectious Diseases, vol. 17, no. 1, pp. 1-8, 2017.

[51] T. Enquebaher, S. Siv, R. Knut, S. Taran, and A. N. Judith, "Staphylococcus aureus and other Staphylococcus species in milk and milk products from tigray region, northern Ethiopia," African Journal of Food Science and Technology, vol. 9, no. 12, pp. 567-576, 2015.

[52] H. F. Massawe, R. H. Mdegela, and R. L. Kurwijila, "Antibiotic resistance of Staphylococcus aureus isolates from milk produced by smallholder dairy farmers in mbeya region, Tanzania," International Journal of One Health, vol. 5, pp. 31-37, 2019.

[53] Y. E. Garoy, B. Y. Gebreab, O. O. Achila et al., "Methicillinresistant Staphylococcus aureus (MRSA): prevalence and antimicrobial sensitivity pattern among patients-a multicenter study in asmara," Canadian Journal of Infectious Diseases and Medical Microbiology, vol. 2019, Article ID 8321834, pp. 1-9, 2019.

[54] F. Adugna, M. Pal, and G. Girmay, "Prevalence and antibiogram assessment of Staphylococcus aureus in beef at municipal abattoir and butcher shops in addis ababa, Ethiopia," BioMed Research International, vol. 2018, Article ID 5017685, 7 pages, 2018.

[55] F. Tessema, "Prevalence and drug resistance patterns of Staphylococcus aureus in lactating dairy cow's milk in 
wolayta sodo, Ethiopia," EC Veterinary Science, vol. 2, no. 5, pp. 226-230, 2016.

[56] Y. Ayele, D. F. Gutema, M. B. Edao et al., "Assessment of Staphylococcus aureus along milk value chain and its public health importance in sebeta, central oromia, Ethiopia," BMC Microbiology, vol. 7, no. 1, pp. 1-7, 2017.

[57] S. Regasa, S. Mengistu, and A. Abraha, "Milk safety assessment, isolation, and antimicrobial susceptibility profile of Staphylococcus aureus in selected dairy farms of mukaturi and sululta town, oromia region, Ethiopia," Veterinary Medicine International, vol. 2019, Article ID 3063185, 11 pages, 2019.

[58] D. Daka, S. G/silassie, and D. Yihdego, "Antibiotic-resistance Staphylococcus aureus isolated from cow's milk in the hawassa area, South Ethiopia," Annals of Clinical Microbiology and Antimicrobials, vol. 11, no. 27, pp. 1-6, 2012.

[59] A. Hassan, A. Hiko, K. Bogale, B. Abera, and B. Tsegaye, "Antimicrobial resistance profiles of Staphylococcus aureus isolates along asella municipal beef abattoir line, South eastern Ethiopia," Journal of Veterinary Science \& Technology, vol. 9, no. 3, pp. 1-5, 2018.

[60] B. Serda, A. Bekele, and D. Abebe, "Prevalence and contamination level of Staphylococcus aureus in raw camel milk and associated risk factors in jigjiga district, eastern Ethiopia," Journal of Veterinary Science \& Technology, vol. 9, no. 1, pp. 1-5, 2018.

[61] M. Tefera, H. Aleme, S. Girma et al., "Antimicrobial susceptibility pattern of $S$. aureus isolated from sheep and goat carcasses," The Open Microbiology Journal, vol. 13, no. 1, pp. 16-20, 2019.

[62] A. C. Fluit, "Livestock-associated Staphylococcus aureus," Clin. Clinical Microbiology and Infection, vol. 18, no. 8, pp. 735-744, 2012.

[63] T. Trnčíková, V. Hrušková, K. Oravcová, D. Pangallo, and E. Kaclíková, "Rapid and sensitive detection of Staphylococcus aureus in food using selective enrichment and realtime PCR targeting a new gene marker," Food Analytical Methods, vol. 2, no. 4, pp. 241-250, 2009.

[64] J. Kemal, B. Sibhat, S. Menkir, Y. Terefe, and Y. Muktar, "Antimicrobial resistance patterns of Salmonella in Ethiopia: a review evolution of Salmonella," African Journal of Microbiology Research, vol. 9, no. 46, pp. 2249-2256, 2015.

[65] Z. Addis, N. Kebede, Z. Worku, H. Gezahegn, A. Yirsaw, and T. Kassa, "Prevalence and antimicrobial resistance of Salmonella isolated from lactating cows and in contact humans in dairy farms of addis ababa: a cross sectional study," BMC Infectious Diseases, vol. 11, no. 1, pp. 1-7, 2011.

[66] S. Balakrishnan, A. Sangeetha, and M. Dhanalakshmi, "Prevalence of Salmonella in chicken meat and its slaughtering place from local markets in orathanadu, thanjavur district, Tamil nadu," Journal of Entomology and Zoology Studies, vol. 6, no. 2, pp. 2468-2471, 2018.

[67] F. M. Tegegne, "Epidemiology of Salmonella and its serotypes in human, food animals, foods of animal origin, animal feed and environment," Journal of Food Nutrition \& Health, vol. 2, no. 1, pp. 7-14, 2019.

[68] G. Tadesse and S. T. Tessema, "A meta-analysis of the prevalence of Salmonella in food animals in Ethiopia," BMC Microbiology, vol. 14, no. 270, pp. 1-9, 2014.

[69] A. J. Musa, I. K. Dauda, A. F. Lawan, D. Diyo, M. M. Meshack, and S. Jauro, "Prevalence and antibiotic sensitivity pattern of Salmonella isolates from milk products and water reservoirs in maiduguri, north-eastern Nigeria,"
IOSR Journal of Agriculture and Veterinary Science, vol. 10, no. 2, pp. 87-92, 2017.

[70] G. Tadesse and Z. E. Gebremedhin, "Prevalence of Salmonella in raw animal products in Ethiopia: a meta-analysis," BMC Research Notes, vol. 8, no. 1, pp. 1-8, 2015.

[71] K. B. Kassaye, J. D. Hassen, and A. K. Leja, "Study on prevalence and distribution of Salmonella isolates from apparently healthy sheep and goats slaughtered at addis ababa abattoir enterprise, Ethiopia," Journal of Veterinary Science \& Technology, vol. 6, pp. 1-5, 2015.

[72] K. Aragaw, B. Molla, A. Muckle et al., "The characterization of Salmonella serovars isolated from apparently healthy slaughtered pigs at addis ababa abattoir, Ethiopia," Preventive Veterinary Medicine, vol. 82, pp. 252-261, 2007.

[73] S. Sanchez, L. C. Hofacre, D. M. Lee, J. J. Maurer, and P. M. Doyle, "Zoonosis update animal sources of salmonellosis in humans," Journal of the American Veterinary Medical Association, vol. 221, no. 4, pp. 492-497, 2002.

[74] D. Taddese, T. Tolosa, B. Deresa, M. Lakow, A. Olani, and E. Shumi, "Antibiograms and risk factors of Salmonella isolates from laying hens and eggs in jimma town, South western Ethiopia," BMC Research Notes, vol. 12, no. 1, pp. 1-7, 2019.

[75] T. Liyuwork, B. Taye, S. Alemu, H. Alemayehu, Z. Sisay, and H. Negussie, "Prevalence and antimicrobial resistance profile of Salmonella isolates from dairy products in addis ababa, Ethiopia," African Journal of Microbiology Research, vol. 7, no. 43, pp. 5046-5050, 2013.

[76] B. Molla, A. Mesfin, and D. Alemayehu, "Multiple antimicrobial-resistant Salmonella serotypes isolated from chicken carcass and giblets in debre zeit and addis ababa, Ethiopia," Ethiopian Journal of Health Development, vol. 17, no. 2, pp. 131-149, 2003.

[77] G. Ejeta, B. Molla, D. Alemayehu, and A. Muckle, "Salmonella serotypes isolated from minced meat beef, mutton and pork in addis ababa," Revue de Médecine Vétérinaire, vol. 155, no. 11, pp. 547-551, 2004.

[78] W. Wabeto, Y. Abraham, and A. A. Anjulo, "Detection and identification of antimicrobial-resistant Salmonella in raw beef at wolaita sodo municipal abattoir, southern Ethiopia," Journal of Health, Population and Nutrition, vol. 36, no. 1, pp. 1-7, 2017.

[79] G. Mulaw, "Prevalence and antimicrobial susceptibility of Salmonella species from lactating cows in dairy farm of bahir dar town, Ethiopia," African Journal of Microbiology Research, vol. 11, no. 43, pp. 1578-1585, 2017.

[80] W. T. Atsbha, T. L. Weldeabezgi, A. K. Seyoum, G. Tafere, and H. H. Kassegn, "Salmonella and risk factors for the contamination of cattle carcass from abattoir of mekelle city, Ethiopia," Cogent Food \& Agriculture, vol. 4, no. 1, pp. 1-8, 2018.

[81] G. Muluneh and M. Kibret, "Salmonella spp. and risk factors for the contamination of slaughtered cattle carcass from a slaughter house of bahir dar town, Ethiopia," Asian Pacific Journal of Tropical Disease, vol. 5, no. 2, pp. 130-135, 2015.

[82] F. Abunna, D. Ashenafi, T. Beyene, D. Ayana, B. Mamo, and R. Duguma, "Isolation, identification and antimicrobial susceptibility profiles of Salmonella isolates from dairy farms in and around modjo town, Ethiopia," Ethiopian Veterinary Journal, vol. 21, no. 2, pp. 92-108, 2017.

[83] G. Girma, "Prevalence, antibiogram and growth potential of Salmonella and Shigella in Ethiopia: implications for public health: a review," Research Journal of Microbiology, vol. 10, no. 7, pp. 288-307, 2015. 
[84] K. Lee, M. Runyon, T. J. Herrman, R. Phillips, and J. Hsieh, "Review of Salmonella detection and identification methods: aspects of rapid emergency response and food safety," Food Control, vol. 47, pp. 264-276, 2015.

[85] J. Wang, Y. Li, J. Chen et al., "Rapid detection of food-borne Salmonella contamination using IMBs-QPCR method based on PagC gene," Brazilian Journal of Microbiology, vol. 49, no. 2, pp. 320-328, 2018.

[86] J. Silva, D. Leite, M. Fernandes, C. Mena, A. P. Gibbs, and P. Teixeira, "Campylobacter spp. As a foodborne pathogen: a review," Frontiers in Microbiology, vol. 2, pp. 1-12, 2011.

[87] T. Woldemariam, D. Asrat, and G. Zewde, "Prevalence of thermophilic Campylobacter species in carcasses from sheep and goats in an abattoir in debre zeit area, Ethiopia," Ethiopian Journal of Health Development, vol. 23, no. 3, pp. 229-233, 2009.

[88] K. Wieczorek, T. Wołkowicz, and J. Osek, “Antimicrobial resistance and virulence-associated traits of Campylobacter jejuni isolated from poultry food chain and humans with diarrhea," Frontiers in Microbiology, vol. 9, pp. 1-11, 2018.

[89] L. Dadi and D. Asrat, "Prevalence and antimicrobial susceptibility profiles of thermotolerant Campylobacter strains in retail raw meat products in Ethiopia," The Ethiopian Journal of Health Development, vol. 22, no. 2, pp. 195-200, 2009.

[90] T. Kassa, S. Gebre-selassie, and D. Asrat, "The prevalence of thermotolerant Campylobacter species in food animals in jimma zone, southwest Ethiopia," Ethiopian Journal of Health Development, vol. 19, no. 3, pp. 225-229, 2006.

[91] H. M. Mughal, "Campylobacteriosis: a global threat," Biomedical Journal of Scientific \& Technical Research, vol. 11, no. 5, pp. 8804-8808, 2018.

[92] R. H. Mdegela, E. H. Nonga, A. H. Ngowi, and R. R. Kazwala, "Prevalence of thermophilic Campylobacter infections in humans, chickens and crows in morogoro, Tanzania," Journal of Veterinary Medicine Series B, vol. 121, pp. 116-121, 2006.

[93] Y. Hagos, M. Berhe, and G. Gugsa, "Campylobacteriosis: emphasis on its status as foodborne zoonosis in Ethiopia," International Journal of Tropical Diseases, vol. 7, pp. 1-8, 2019.

[94] S. Nigatu, A. Mequanent, R. Tesfaye, and L. Garedew, "Prevalence and drug sensitivity pattern of Campylobacter jejuni isolated from cattle and poultry in and around gondar town, Ethiopia," Global Veterinaria, vol. 14, no. 1, pp. 43-47, 2015.

[95] N. Asuming-Bediako, P. A. Kunadu, S. Abraham, and I. Habib, "Campylobacter at the human-food interface: the african perspective," Pathogens, vol. 8, no. 2, pp. 1-30, 2019.

[96] D. I. Ogden, F. J. Dallas, M. MacRae et al., "Europe PMC funders group Campylobacter excreted into the environment by animal Sources : prevalence, concentration shed, and host association," Foodborne Pathogens and Disease, vol. 6, no. 10, pp. 1161-1170, 2014.

[97] G. Feierl and S. Jelovcan, "Campylobacteriosis in Austria: situation and trends wiener klinische wochenschrift campylobacteriosis in Austria situation and trends," Wiener klinische Wochenschrift, vol. 121, pp. 103-107, 2014.

[98] R. Khoshbakht, M. Tabatabaei, S. Hoseinzadeh, and M. Raeisi, "Prevalence and antibiotic resistance profile of thermophilic Campylobacter spp of slaughtered cattle and sheep in shiraz, Iran," Veterinary Research Forum, vol. 7, no. 3, pp. 241-246, 2016.
[99] A. A. Shad and A. W. Shad, "Review of food-borne microorganism: Campylobacter species," Journal of Food: Microbiology, Safety \& Hygiene, vol. 4, p. 141, 2019.

[100] Y. Chanyalew, D. Asrat, P. Amavisit, and W. Loongyai, "Prevalence and antimicrobial susceptibility of thermophilic Campylobacter isolated from sheep at debre birhan," The Kasetsart Journal (Natural Science), vol. 47, pp. 551-560, 2013.

[101] A. Hadush and M. Pal, "Detection of Campylobacter jejuni from food and its epidemiology," Journal of Public Health and Epidemiology, vol. 5, no. 9, pp. 357-361, 2013.

[102] T. S. Omara, E. H. Fadaly, and A. M. A. Barakat, "Public health hazard of zoonotic Campylobacter jejuni reference to Egyptian regional and seasonal variations," Research Journal of Microbiology, vol. 10, no. 8, pp. 343-354, 2015.

[103] H. Jribi, H. Sellami, S. Mariam et al., "Isolation and identification of Campylobacter spp. from poultry and poultry by-products in Tunisia by conventional culture method and Multiplex real-time PCR," Journal of Food Protection, vol. 80, no. 10, pp. 1623-1627, 2017.

[104] J. O'Grady, M. Ruttledge, S. Sedano-Balbas, J. T. Smith, T. Barry, and M. Maher, "Rapid detection of Listeria monocytogenes in food using culture enrichment combined with real-time PCR," Food Microbiology, vol. 26, no. 1, pp. 4-7, 2009.

[105] A. F. Derra, K. Susanne, D. P. Monga et al., "Occurrence of Listeria spp. in retail meat and dairy products in the area of addis ababa, Ethiopia," Foodborne Pathogens and Disease.vol. 10, no. 6, pp. 577-579, 2013.

[106] N. N. Odu and O. I. Okonko, "Prevalence and antibiotic susceptibility of Listeria monocytogenes in retailed meats in port harcourt metropolis, Nigeria," J. Journal of Public Health Research, vol. 7, no. 4, pp. 91-99, 2017.

[107] S. Mulu and M. Pal, "Studies on the prevalence, risk factors, public health implications and antibiogram of Listeria monocytogenes in sheep meat collected from municipal abattoir and butcher shops in addis ababa," Journal of Foodborne and Zoonotic Diseases, vol. 4, no. 1, pp. 1-14, 2016.

[108] B. Molla, R. Yilma, and D. Alemayehu, "Listeria monocytogenes and other Listeria species in retail meat and milk products in addis ababa, Ethiopia," Ethiopian Journal of Health Development, vol. 18, no. 3, pp. 1-10, 2005.

[109] G. R. Vaidya, P. S. Chaudhary, N. N. Zade et al., "Prevalence, virulence and antibiotic susceptibility of Listeria monocytogenes recuperated from slaughtered goats and pigs of nagpur, Central India," International Journal of Current Microbiology and Applied Sciences, vol. 7, no. 4, pp. 15661578, 2018.

[110] L. Garedew, A. Taddese, T. Biru et al., "Prevalence and antimicrobial susceptibility profile of Listeria species from ready-to-eat foods of animal origin in gondar town, Ethiopia," BMC Microbiology, vol. 15, no. 1, pp. 1-6, 2015.

[111] M. Pal and H. Awel, "Public health significance of Listeria monocytogenes in milk and milk products: an overview," Journal of Veterinary Public Health, vol. 12, no. 1, pp. 1-5, 2014.

[112] S. Lee, P. L. Cappato, T. J. Guimarães et al., "Listeria monocytogenes in milk: occurrence and recent advances in methods for inactivation," Beverages, vol. 5, no. 1, pp. 1-14, 2019.

[113] R. Ranjbar and M. Halaji, "Epidemiology of Listeria monocytogenes prevalence in foods, animals and human origin from Iran: a systematic review and meta-analysis," $B M C$ Public Health, vol. 18, no. 1, pp. 1-12, 2018. 
[114] N. D. Nayak, V. C. Savalia, H. I. Kalyani, R. Kumar, and P. D. Kshirsagar, "Isolation, identification, and characterization of Listeria spp. from various animal origin foods," Veterinary World, vol. 8, no. 6, pp. 695-701, 2015.

[115] P. Sanlibaba and U. B. Tezel, "Prevalence and characterization of Listeria species from raw milk and dairy products from çanakkale province," Turkish Journal of Agriculture-Food Science and Technology volume, vol. 6, no. 1, pp. 61-64, 2018.

[116] Y. Girma and B. Abebe, "Identification and antimicrobial susceptibility of Listeria species from raw bovine milk in debre-birhan town, Ethiopia," Journal of Zoonotic Diseases and Public Health, vol. 2, no. 1, pp. 1-7, 2018.

[117] M. Jami, M. Ghanbari, M. Zunabovic, J. K. Domig, and W. Kneifel, "Listeria monocytogenes in aquatic food products-a review," Comprehensive Reviews in Food Science and Food Safety, vol. 13, no. 5, pp. 798-813, 2014.

[118] N. Paudyal, V. Anihouvi, J. Hounhouigan et al., "Prevalence of foodborne pathogens in food from selected african countries-a meta-analysis," International Journal of Food Microbiology, vol. 249, pp. 35-43, 2017.

[119] S. C. Rodrigues, C. V. C. Sá, and B. C. Melo, “An overview of Listeria monocytogenes contamination in ready to eat meat, dairy and fishery foods," Ciencia Rural, vol. 47, no. 2, pp. 1-8, 2017.

[120] K. Dhama, K. Karthik, R. Tiwari et al., "Listeriosis in animals, its public health significance (Food-Borne zoonosis) and advances in diagnosis and control: a comprehensive review," The Veterinary Quarterly, vol. 35, no. 4, pp. 211-235, 2015.

[121] A. D. Alewy, A. H. Ba-Salamah, A. Shater, S. A. Al Sanabani, and A. M. F. Abd, "Prevalence of Listeria monocytogenes in red meat in dhamar governorate/Yemen," International Journal of Medical Research \& Health Sciences, vol. 2, no. 12, pp. 73-78, 2016.

[122] T. E. Seyoum, A. D. Woldetsadik, K. T. Mekonen, A. H. Gezahegn, and A. W. Gebreyes, "Prevalence of Listeria monocytogenes in raw bovine milk and milk products from central highlands of Ethiopia," The Journal of Infection in Developing Countries, vol. 9, no. 11, pp. 1204-1209, 2015.

[123] S. Gebretsadik, T. Kassa, H. Alemayehu, K. Huruy, and N. Kebede, "Isolation and characterization of Listeria monocytogenes and other Listeria species in foods of animal origin in addis ababa, Ethiopia," Journal of Infection and Public Health, vol. 4, no. 1, pp. 22-29, 2011.

[124] B. Borovic, B. Tatjana, L. Brankica et al., "Prevalence of Listeria monocytogenes in ready-to-eat food of animal origin," Technology MESA, vol. 55, no. 2, pp. 117-122, 2014.

[125] P. Navratilova, J. Schilegelova, A. Sustackva, E. Napravnikova, J. Lukasova, and E. Klimova, "Prevalence of Listeria monocytogenes in milk, meat and foodstuffof animal origin and the phenotype of antibiotic resistance of isolated strains," Veterinary Medicine-Czech.vol. 49, no. 7, pp. 243-252, 2004.

[126] D. Leong, A. Alvarez-Ordóñez, and K. Jordan, “Monitoring occurrence and persistence of Listeria monocytogenes in foods and food processing environments in the republic of Ireland," Frontiers in Microbiology, vol. 5, pp. 1-8, 2014.

[127] W. W. Reda, K. Abdel-Moein, A. Hegazi, Y. Mohamed, and K. Abdel-Razik, "Listeria monocytogenes: an emerging foodborne pathogen and its public health implications," The Journal of Infection in Developing Countries, vol. 10, no. 2, pp. 149-154, 2016.

[128] P. Rossmanith, M. Krassnig, M. Wagner, and I. Hein, "Detection of Listeria monocytogenes in food using a combined enrichment/real-time PCR method targeting the PrfA gene," Research in Microbiology, vol. 157, no. 8, pp. 763-771, 2006.

[129] M. Kurpas, K. Wieczorek, and J. Osek, "Ready-to-Eat meat products as a source of Listeria monocytogenes," Journal of Veterinary Research, vol. 62, no. 1, pp. 49-55, 2018.

[130] C. J. Thorns, "Bacterial food-borne zoonoses changing Perspectives : 20th and 21 St centuries," Revue Scientifique et Technique de l'OIE, vol. 19, no. 1, pp. 226-239, 2000.

[131] S. Abreham, A. Teklu, E. Cox, and S. T. Tessema, "Escherichia coli O157: H7: distribution, molecular characterization, antimicrobial resistance patterns and source of contamination of sheep and goat carcasses at an export abattoir, mojdo, Ethiopia," BMC Microbiology, vol. 19, no. 1, pp. 1-14, 2019.

[132] M. Taye, T. Berhanu, Y. Berhanu, F. Tamiru, and D. Terefe, "Study on carcass contaminating Escherichia coli in apparently healthy slaughtered cattle in haramaya university slaughter house with special emphasis on Escherichia coli O157:H7, Ethiopia," Journal of Veterinary Science \& Technology, vol. 4, no. 1, pp. 1-3, 2013.

[133] T. Bekele, G. Zewde, G. Tefera, A. Feleke, and K. Zerom, "Escherichia coli O157:H7 in raw meat in addis ababa, Ethiopia: prevalence at an abattoir and retailers and antimicrobial susceptibility," The International Journal of Food Contamination, vol. 1, no. 1, pp. 1-9, 2014.

[134] E. Y. Messele, D. R. Abdi, T. D. Tegegne, and K. S. Bora, "Analysis of milk-derived isolates of E. coli indicating drug resistance in Central Ethiopia," Tropical Animal Health and Production, vol. 51, no. 3, pp. 661-667, 2018.

[135] A. Assefa, "Prevalence of Escherichia coli O157:H7 in foods of animal origin in Ethiopia: a meta-analysis," Cogent Food \& Agriculture, vol. 5, no. 1, pp. 1-10, 2019.

[136] A. Hiko, D. Asrat, and G. Zewde, "Occurrence of Escherichia coli O157:H7 in retail raw meat products in Ethiopia," Journal of Infection in Developing Countries, vol. 2, no. 5, pp. 389-393, 2008.

[137] G. Mersha, D. Asrat, M. B. Zewde, and M. Kyule, "Occurrence of Escherichia coli O157:H7 in faeces, skin and carcasses from sheep and goats in Ethiopia," Letters in Applied Microbiology, vol. 50, no. 1, pp. 71-76, 2010.

[138] B. C. Kiranmayi and N. Krishnaiah, "Detection of Escherichia coli O157: H7 prevalence in foods of animal origin by cultural methods and PCR technique," Veterinary World, vol. 3, no. 1, pp. 13-16, 2010.

[139] R. Abdissa, W. Haile, T. A. Fite et al., "Prevalence of Escherichia coli O157: H7 in beef cattle at slaughter and beef carcasses at retail shops in Ethiopia," BMC Infectious Diseases, vol. 17, no. 1, pp. 1-6, 2017.

[140] P. Ayscue, C. Lanzas, R. Ivanek, and Y. T. Gröhn, "Modeling on-farm Escherichia coli O157:H7 population dynamics," Foodborne Pathogens and Disease, vol. 6, no. 4, pp. 461-470, 2009.

[141] F. A. Beyi, T. A. Fite, E. Fite et al., "Prevalence and antimicrobial susceptibility of Escherichia coli $\mathrm{O} 157$ in beef at butcher shops and restaurants in Central Ethiopia," BMC Microbiology, vol. 17, no. 1, pp. 1-6, 2017.

[142] P. Saeedi, M. Yazdanparast, E. Behzadi et al., "A review on strategies for decreasing E. coli O157:H7 risk in animals," Microbial Pathogenesis, vol. 103, pp. 186-195, 2017.

[143] A. M. Karmali, V. Gannon, and M. J. Sargeant, "Verocytotoxin-producing Escherichia coli (VTEC)," Veterinary Microbiology, vol. 140, no. 3-4, pp. 360-370, 2010.

[144] M. Farahmandfar, N. Moori-Bakhtiari, S. Gooraninezhad, and M. Zarei, "Comparison of two methods for detection of 
E. coli $\mathrm{O} 157 \mathrm{H} 7$ in unpasteurized milk. Iran," Journal of Microbiology, vol. 8, no. 5, pp. 282-287, 2016.

[145] K. A. Deisingh and M. Thompson, "Strategies for the detection of Escherichia coli O157:H7 in foods," Journal of Applied Microbiology, vol. 96, no. 3, pp. 419-429, 2004.

[146] H. Pennington, "Escherichia coli O157," The Lancet, vol. 376, pp. $1428-1435,2010$. 